\title{
The Hell Creek Formation and its contribution to the Cretaceous- Paleogene Extinction: a short primer
}

\author{
David E. FASTOVSKY ${ }^{1,2^{*}}$, Antoine BERCOVICI ${ }^{3}$
}

${ }^{1}$ University of Vienna, UZA II, Dept. fur Lithosphärenforschung, Althanstraße 14, A-1090 Wien, Österreich.

${ }^{2}$ Department of Geosciences, University of Rhode Island, Kingston, RI 02881, USA.

${ }^{3}$ Department of Paleobiology MRC-121, National Museum of Natural History, Smithsonian Institution, 10th Street and Constitution Ave. NW, Washington DC 20560-0121, USA.

*Corresponding author: David E. Fastovsky, defastov@uri.edu

\begin{abstract}
:
Although it represents but one geographic data point, the uppermost Maastrichtian Hell Creek Formation (HCF), exposed in the upper Great Plains of the North American craton, remains the most studied source for understanding the final $1.5 \mathrm{Myr}$ of the Mesozoic Era in the terrestrial realm. Because it lies conformably below the earliest Paleocene Fort Union Formation, and together these two units preserve a rich fauna and flora, much of what is understood about the terrestrial Cretaceous-Paleogene (K-Pg) boundary comes from this sequence.
\end{abstract}

The HCF has been reconstructed as an expansive, fluvially drained, low coastal plain, built out, to the west, against the Laramide Orogen, and to the east, against the ultimate transgression (Cannonball) of the Western Interior Sea. Its meandering rivers and moist soils supported a multi-tiered angiosperm-dominated flora and rich insect and vertebrate faunas, 
including dinosaurs, crocodilians, squamates, turtles, and mammals. A dramatic facies change representing the initiation of catastrophic flooding is preserved, within available levels precision, at the $\mathrm{K}-\mathrm{Pg}$ boundary.

High-precision stratigraphy has proven difficult in this lenticular fluvial system. Where present, the boundary can be recognized by the bipartite boundary claystone; otherwise, palynostratigraphy has proven a powerful tool. Numerical dates have been successfully obtained from in tonsteins at the boundary and above, in the Fort Union; however, these have proven elusive below the boundary within the HCF. The K-Pg boundary in this region is dated at 66.043 Ma (Renne et al., 2013). Magnetostratigraphic studies have been carried out in the HCF; although all but one have lacked numerical dates, these have been used for correlations of widespread, disjunct exposures and for the estimation of sedimentation rates.

The palynoflora is largely homogenous through the HCF; at the K-Pg boundary, it shows an abrupt $\sim 30 \%$ extinction. This makes it a powerful tool for identification of the $\mathrm{K}-\mathrm{Pg}$ boundary, although because the boundary is identified on absence of Cretaceous taxa rather than presence of earliest Paleocene taxa, several competing methods have been applied to identifying the K-Pg boundary using pollen.

The macroflora, consisting largely of leaves, consists of three successive floras, showing increasing diversity through the HCF. The ultimate of these three floras undergoes an abrupt 57\% extinction; taken as a whole, however, the macroflora undergoes a $78 \%$ extinction at the $\mathrm{K}-\mathrm{Pg}$ boundary.

The best data available for dinosaurs - including archaic Aves - show an abrupt extinction. By contrast, salamanders and other lissamphibians, as well as chelonians, cross the boundary virtually without perturbation. Squamates appear to have suffered significant extinctions at the K-Pg boundary, as did euselachians (elasmobranchs) and insects. Mammals 
suffered a $75 \%$ extinction; however, some of this figure cannot be shown to have occurred in less than the last $500 \mathrm{kyr}$ of the Cretaceous, and thus has been potentially attributable to causes other than a bolide impact. Taken together, the survivorship patterns are concordant with the catastrophic inception of ubiquitous flooding characterizing the K-Pg boundary. While the key $\mathrm{K}-\mathrm{Pg}$ boundary question in the HCF was once the rate of the biotic extinction, it has moved to the distinction between single-cause scenarios, with the Chicxulub bolide as agent of extinction, and multi-cause scenarios, uniting habitat partitioning, Deccan flood-basalt volcanism, climate change, competition, and bolide impact. Not every potential environmental perturbation need be a mechanism for the extinction: parsimony and the data continue to be concordant with a bolide impact as the single agent of the terrestrial $\mathrm{K}-\mathrm{Pg}$ mass extinction.

Key words: Hell Creek Formation, Maastrichtian, Mass Extinction, Cretaceous-Paleogene boundary, Dinosaurs, Paleoenvironment 


\section{Introduction}

The Hell Creek Formation (HCF), from the upper Great Plains of the North American Western Interior remains the global standard for understanding terrestrial CretaceousPaleogene $(\mathrm{K}-\mathrm{Pg})$ extinction events. This is because the HCF preserves an extraordinarily abundant and diverse terrestrial biota within the same stratigraphic units. The biota is comprised of fossil floras (plant fossils and palynomorphs), vertebrates (fish to dinosaurs; mega- to microvertebrates), invertebrates, non-palynomorph microfossils, and a range of trace fossils. Along with these, the HCF contains critical geochemical markers such as multiple iridium anomalies (e.g., Bohor et al., 1984; Nichols et al., 2000) and a putative K-Pg isotopic excursion (Arens and Jahren, 2000, 2002; Arens et al., 2014; but see below). In turn, these indicators can all be assessed in their proper paleoenvironmental and paleoecological context(s). Moreover, the HCF records these latest Cretaceous terrestrial biotas and markers with, by the standards of terrestrial deposits, a high degree of stratigraphic resolution (Dingus, 1984).

While there has been ongoing interest in the HCF since the turn of the $20^{\text {th }}$ century (see Clemens and Hartman, 2014), attention to the unit and its fossil biota increased considerably after the publication of the Alvarez et al. (1980) hypothesis of dinosaur extinction by asteroid impact. Because of its rich biota and stratigraphic completeness, the HCF has uniquely been the object of a significant history of quantitative study (see Fastovsky and Sheehan, 2005) to address key questions about the terrestrial K-Pg extinction. In general, such treatments have generally revolved around the rate at which the extinction took place; an instantaneous extinction would be concordant with the hypothesis of an asteroid impact as cause; a more gradual extinction, or ecosystemic deterioration have been interpreted as concordant with other - perhaps more earthbound - causes. 
A sense for the magnitude of the interest in the HCF can be obtained from the fact that two large Geological Society of America Special Paper edited volumes have been published (nos. 361 and 503; Hartman et al. 2002; Wilson et al. 2014a, respectively), exclusively devoted the HCF, its fauna, and its bearing upon the K-Pg boundary. This contribution, therefore, is a necessarily brief, introductory abstract of a very large literature.

\section{Geological Setting}

The HCF is a fine-grained, fluvially derived, siliciclastic $\sim 100$ m-thick unit preserved throughout the Williston Basin in the upper Great Plains of the Western Interior of the United States and southern Canada (Fig. 1). It arose as a sedimentary prism derived from materials shed from the Rocky Mountain Laramide Orogeny (Fastovsky, 1986; Peterson, 1986; Murphy et al., 2002) and may have existed for less than the very last $1.4 \mathrm{Myr}$ of the latest Cretaceous (Hicks et al., 2002). Superjacent to it is the Fort Union Formation, the basal part of which is (confusingly) known as the "Tullock Formation" in eastern Montana and the "Ludow Member" in western North Dakota. For simplicity here, we use the designation "basal Fort Union" to refer to the Tullock/Ludlow sedimentary interval. Below the HCF is the transitional marine-to-brackish Fox Hills Formation. These relationships are shown in Fig. 2.

The Hell Creek is generally reckoned to have been "discovered" (at least named) by the legendary Barnum Brown, the early $20^{\text {th }}$ century, peripatetic American Museum of Natural History fossil collector (see Dingus and Norell, 2010). He eventually described the unit (Brown, 1907), although the focus of his interest and description was largely paleontological (he had discovered the type specimen of Tyrannosaurus rex there in 1902). During the next $\sim 60$ years, interest in the area was driven largely by the search for coal, natural gas and oil, by the development of the Fort Peck dam (and reservoir), and by the continued recovery of fossils by field parties from several (generally) eastern U.S. museums. 
By the early 1960s, a recognizably modern concept of the K-Pg boundary in the region had crystalized, and pioneering work by B. Erickson, R.E. Sloan and L. Van Valen included working hypotheses about the nature of the boundary and associated extinction(s). Concomitantly, a modern understanding of the regional geological relationships of the relevant formations and members was developed by the early 1950s, driven largely by workers from the U.S. and relevant state geological surveys. A very complete, detailed, and informative account of this history through 1980 is given in Clemens and Hartman (2014).

Early studies by Moore (1976), Frye (1969) and Butler (1980) attempted to characterize the paleoenvironments of the Hell Creek. These studies established formal members that generally proved to be unrecognizable outside the limited area where they were described. In time, however, modern sedimentological approaches by Fastovsky and Dott (1986), Fastovsky (1986; 1987), Fastovsky and McSweeney (1987), Belt et al. (1984; 1997), Johnson (1989), Retallack (1994), Murphy et al. (1995; 2002), all converged on the recognition of HCF deposits as representing a meandering fluvial system, generally draining to the SE, with forested, low-lying, extensive floodplain sedimentation. All of these workers identified a variety of facies (Fig. 3A-E) representing repetitive architectural elements in an aggrading fluvial system.

Fastovsky and McSweeney (1987) and Retallack (1994) reconstructed catenary sequences of hydromorphic paleosols suggesting an abundance of water with a very high water table. Observing the distinctive facies change that characterizes the lithostratigraphic HCF - Fort Union contact, Fastovsky (1987) proposed that the K-Pg boundary occurred concomitantly with the surface expression of the water table, forming regional "ponding". This is manifested by an abrupt transition from gleyed hydromorphic paleosols in the HCF (Fig. 3C and D) to extensive ponds or lakes, and peat mires (see below) that characterize the lowest deposits of the Fort Union (Fastovsky and McSweeney, 1987; Retallack, 1994). The 
extensive ponds and lakes are today represented by a distinctive, widespread iron-stained laminated siltstone facies (Fig. 3F; the "variegated beds" of Archibald, 1982). This facies shows an unusually pervasive signal of suspension settling, as if wholesale landscape flooding took place that resisted conventional draining. The peat mires are represented by local, thin lignite coal deposits (Fig. 3G and H). Both types of Fort Union deposits reflect ubiquitous standing water and comparatively high rates of deposition. This more or less abrupt facies change is shown in Fig. 4.

Although the HCF sedimentary prism presumably prograded against a retreating Western Interior Sea, definitive deltaic sedimentary environments, proposed on the basis of paleogeographic relationships (e.g., Cherven and Jacob (1985), have never really been found in Hell Creek deposits. However, at least two tongues of Hell Creek marine sedimentary rocks have been observed to the west, the "Breien Member" (Laird and Mitchell, 1942; Hoganson and Murphy, 2002) and the "Cantapeta Advance" (Murphy et al., 2002). Both can be interpreted as early pulses of a transgressive Cannonball Sea (see below); thus the Hell Creek was likely laid down during a eustatic transgressive phase of the Western Interior Sea. This has ramifications for some extinction models (see below).

Fig 2, taken from Johnson et al. (2002), is the best available model for the large-scale stratigraphic relationships of the HCF. It suggests the existence of an unconformity at the base of the HCF. Insofar as the magnetostratigraphy upon which it is based was carried out without geochronological control (see below), the precise age of this unconformity should not yet be regarded as definitive.

\section{Stratigraphy}

\subsection{Lithostratigraphy}


Stratigraphy within the Hell Creek has historically been its Achilles' heel. Precise lateral correlations would have allowed disparate localities to be linked temporally, however, as noted by Fastovsky and Dott, (1986), Fastovsky (1987) and Johnson (1992), despite the apparent illusion of lateral continuity, the fluvially derived beds of the HCF are highly lenticular, and cross cut each other in ways which preclude high-precision correlations. The only way to assure temporal correlation is to physically trace individual beds, an impossibility because of the limitations of outcrop exposure and because the beds themselves are ultimately not continuous.

The most notorious lithostratigraphic marker in the HCF is actually just above it: the $\mathrm{K}-\mathrm{Pg}$ boundary, equated with the top of the HCF, was said to be identified by the appearance of the first (lowest) more or less continuous ("persistent") lignitic coal (Fig. 3G), dubbed by Collier and Knechtel (1939), the "Z-coal”. Successively younger coals were labeled with successively earlier letters in the alphabet (Collier and Knechtel, 1939). For all that, however, Collier and Knechtel (1939) recognized that these lignites were lenticular; the problem was, if they were lenticular, and not the same single bed, how could they be reasonably imputed to be isochronous? If they are not isochronous, then which one (or ones) represent(s) the K-Pg boundary?

The lignites are the remains of localized, swampy peat mires that formed in HCF fluvial system. Fastovsky and McSweeney (1987) presented a catenary sequence in which these deposits represented geographically limited areas of low topography in the floodplain setting. How, then, could they possibly be used for precision correlations?

In the absence of better correlative tools, the need to use the coals as time markers plagued workers in the field, particularly as the need for stratigraphic precision became imperative for understanding whether or not the extinctions recorded in the HCF conformed to, or contradicted, the Alvarez et al. (1980) asteroid impact hypothesis. Recognizing that 
single, lowest coal had no widespread isochronous reality, the single "Z-coal" came to be referred to as the "Z-coal complex", with "upper" and "lower" Z-coals (Archibald, 1982). This failed to remove the sense of high temporal precision implied by the name "Z-coal" (and indeed, some workers adopted a yet more complicated coal nomenclature (vis, the “widespread" IrZ and HFZ of Swisher et al., 1993); but eventually, a number of workers independently rediscovered and reaffirmed that there was not a single, regional Z-coal, or regional pattern of Z-coals (Fastovsky, 1987; Johnson, 1992).

With the discontinuity of the lowest coals recognized and its problematic implications for the K-Pg boundary understood, the coincidence of the lowest coal and the K-Pg-boundary came to be challenged. Nichols and Johnson (2002 and references therein), used palynostratigraphy to demonstrate that the HCF-Fort Union formational contact was in places almost $3 \mathrm{~m}$ removed from K-Pg boundary as identified by palymorphs. Nichols and Johnson (2002), for example, refer to "Fort Union strata of Cretaceous age", in which typical Cretaceous pollen species persist within the lowermost part of the Fort Union Formation. Subsequent work by Bercovici et al. (2009; see also Moore et al., 2014), however, demonstrated that in these detrital, fluvial sedimentary deposits, the presence-absence method of pollen analysis used by D.J. Nichols to identify the K-Pg boundary could potentially misplace the boundary. This issue is discussed in detail in Sec. 3.1.1 Palynology (below).

In the end, our thinking has come full circle: as an operational definition for the formational (lithostratigraphic) and K-Pg (chronostratigraphic) boundaries, the onset of localized peat mire deposition, identified by the stratigraphically lowest, local, thin, coal layers, and extensive laminated silt -rich flood deposits is empirically effective (e.g., Brown, 1952) and, at a certain level of stratigraphic precision, probably correct.

\section{2. iridium}


The discovery of the iridium anomaly, and of the multiple associated mineralogical and geochemical evidence (shocked quartz, Ni spinels) associated with the geologically instantaneous Chicxulub impact event (e.g., Alvarez et al., 1980, 1982, 1984; Orth et al., 1981, 1982; Bohor and Izett, 1986; Izett, 1990; Claeys et al., 2002), provided a global way to correlate extinction events across marine and terrestrial sections. Therefore, it was a key discovery that at the top of the HCF, iridium, along with shocked quartz (Bohor et al., 1984) and other impact indicators (Alvarez et al. 1980) are preserved in the upper layer of distinctive bipartite tonsteins (Pollastro and Pillmore, 1987; Fastovsky et al., 1989), themselves contained within the basal K-Pg coals (Fig. 5). The restriction of the Ir-bearing tonsteins to the lignites has been attributed to the low energy of the shallow peat mires that characterized HCF landscapes at the time of the K-Pg boundary. The iridium deposits, therefore, are at least as discontinuous as the coal deposits in which they are found.

Regardless, of continuity, once an iridium anomaly was found in the lowest lignite deposits of the HCF (Bohor et al., 1984), it was widely recognized this could constitute the most precise isochron known for the region. Early on, iridium anomalies linked the $\mathrm{K}-\mathrm{Pg}$ boundary in the Raton Basin of New Mexico with that of Brownie Butte (eastern Montana) and as time went on, a number of other $\mathrm{K}-\mathrm{Pg}$ iridium anomalies were recovered throughout the region (Nichols and Johnson, 2002; Moore et al., 2014). These constituted the first regionally correlative isochron, have global correlative power, and remain valid to this day.

\subsection{Magnetostratigraphy}

With the rarity of iridium and the imprecision of other stratigraphic markers, a number of workers attempted magnetostratigraphic treatments of the HCF. The base of the unit is somewhere within Chron 30n; and the K-Pg boundary does not coincide with a magnetic reversal; rather, it occurs somewhere within Chron 29r (see Fig. 1). For this reason, 
magnetostratigraphy was potentially a powerful tool: if one could identify the K-Pg boundary lithostratigraphically, and then find Chron 29r-Chron 29n boundary, sedimentation rates were potentially possible to calculate. Following an early hiccup regarding the polarity (and thus correlatability) of the New Mexican vs. the Montana K-Pg boundaries (Archibald et al., 1982), successful magnetostratigraphic studies were carried out in the HCF. Swisher et al. (1993) carried out a magnetostratigraphic study in the Hell Creek area; they obtained ${ }^{40} \mathrm{~K}-$ ${ }^{40} \mathrm{Ar}$ dates which they tied into a magnetic polarity scale covering the upper Hell Creek and the basal Fort Union. That work became, as noted by Clemens and Hartman (2014), a "composite reference section" for $~ 20$ years in the eastern Montana study areas.

Building upon the study of Swisher et al. (1993), LeCain et al. (2014) constructed a thick paleomagnetic sequence across four (composite) sections, running from Chron 30n (or even 30r) - Chron 28n. Their work demonstrated a broad continuity between position (HCF; basal Fort Union) and early North American Land Mammal Ages (NALMA, e.g., Lancian, and the Puercan), with a view towards tying fossil localities into the paleomagnetic timescale to facilitate extrabasinal correlations.

Lund et al. (2002) appeared to isolate an estimated $\sim 90,000 \mathrm{yr}$ diachroneity between the K-Pg boundary - as identified by pollen and the HCF - Fort Union formational contact in North Dakota, but found the two to be synchronous in eastern Montana.

Working in the North Dakota exposures of the Hell Creek, Hicks et al. (2002) used orbital forcing to obtain the duration of Chron 29r, and then extrapolated sedimentation rates obtained from the 29r portion of the HCF to its base (part of Chron 30n), to infer that the duration of the unit is $\sim 1.36 \mathrm{Myr}$, although they acknowledged that a range of durations from 1.05 Myr - 1.9 Myr might be possible (Hicks et al., 2002). Peppe et al. (2009) extended the work of Hicks et al. (2002) into the basal Fort Union Formation (Ludlow Member), 
determining that it was $2.3-2.6 \mathrm{Myr}$ in duration; a metric against which the $\mathrm{K}-\mathrm{Pg}$ recovery could potentially be measured.

With the exception of Swisher et al. (1993), all of these paleomagnetic studies are hampered by an absence geochronological tie points. In highly heterogenous deposits, deposited at highly variable rates, this approach is of uncertain, and at best variable, reliability. Sixty percent of sedimentation in the HCF is composed of fine-grained (floodplainrelated) deposits (Fastovsky, 1987; see also Retallack, 1994); however, even that figure means that $40 \%$ of the thickness of the HCF - the channel sequences - was deposited in effect instantaneously. Because thickness is the means by which sedimentation rates are calculated, the precision of these studies is thus potentially compromised.

\subsection{Geochronology}

Geochronology could of course determine the temporal position of the HCF-Fort Union contact, as well as potentially be used for rates of extinction. In fact, however, the detrital deposits of the HCF have proven to be unsuited to dating; despite some accounts to the contrary, petrographic analysis shows that the "bentonites" of the HCF are detrital and not volcanogenic (Fastovsky, 1986) and the required sanidines (K-Ar dating; Ar-Ar dating) and zircons (U-Pb dating) are not present. They are present, however, in deposits above the HCF, especially in tonsteins preserved in the Fort Union coals and have been used to constrain earliest Paleogene Land Mammal ages and for reconstructions of the pace of the recovery (e.g., Swisher et al., 1993; Renne et al., 2013; Sprain et al., 2015).

Still, with tonsteins preserved in the " $Z$ coals", dates have been obtained from the $\mathrm{HCF}$ - Fort Union lithostratigraphic contact. Here we review only those of the last 20 years, since these surely supersede earlier work. Swisher et al. (1993) obtained three Ar-Ar dates from sanidines in three different coals in the "Z-coal complex": IrZ, $65.16 \pm 0.04 \mathrm{Ma}$; Z, 
$65.01 \pm 0.03$ Ma; HFZ, $64.77 \pm 0.06$ Ma. These dates have subsequently required recalibration (see Renne et al., 1998; Wilson, 2004).

Renne et al. (2013) demonstrated that the HCF - Fort Union lithostratigraphic contact is coincident with the Chicxulub impact (and thus, with the K-Pg boundary, see Schulte et al., 2010) within a level of precision of 32,000 years. Using ${ }^{40} \mathrm{Ar}-{ }^{39} \mathrm{Ar}$, they dated five " $\mathrm{Z}$ coals" from the Hell Creek (Montana) area to obtain a combined date of 66.043 $\pm 0.011 / 0.043$ Ma for sanidines extracted from the tonsteins, matching the combined date of $66.038 \pm 0.025 / 0.049$ Ma obtained from glass melt droplets (tektites) from Beloc, Haiti.

In a subsequent, extensive sanidine-based ${ }^{40} \mathrm{Ar}-{ }^{39} \mathrm{Ar}$ tephra geochronology of the eastern Montana study region (again, perforce focusing on the Fort Union, because the coal sequences in it preserve datable tephras), Sprain et al. (2015) showed that in several localities in the eastern part of the study area, the tephras in the most basal lignites were mildly offset in time from the $\mathrm{K}-\mathrm{Pg}$ boundary. In the western part, they were synchronous. They interpreted their data to show a multi-thousand year paleoenvironmental "transition" from the high-watertable, hydromorphic paleosols of the HCF to the flooded landscapes of the Fort Union Formation.

\subsection{Chemostratigraphy}

A well-known K-Pg marine isotopic excursion from El Kef, Tunisia (e,g., Keller and Lindinger, 1989) in combination with an awareness of the difficulties of correlation discussed above, suggested to several authors that if a carbon isotopic stratigraphy could be constructed in the Hell Creek, it could be a powerful tool for correlation. Accordingly, several were constructed (Arens and Jahren 2000; 2002; Therrien et al., 2007; Maruoka et al., 2007). Modest negative $(1-\sim 2.8 \%$ o carbon isotopic shifts were obtained at or near $\mathrm{K}-\mathrm{Pg}$ boundaries in Alberta, Canada, Montana, and North Dakota. Ultimately a fossilierous 
reference section (Herman Ridge, eastern Montana) was proposed by Arens et al. (2014). The published data to date, however, were reviewed by Grandpre et al. (2013), who measured similar carbon isotopic data at Mud Buttes, North Dakota (where there is an unambiguous KPg boundary containing an iridium anomaly), and then observed that all of the $\mathrm{K}-\mathrm{Pg}$ boundary isotopic shifts recorded in all of the data bases (including that from Mud Buttes) were statistically indistinguishable from any number of similar carbon isotopic offsets recorded above and below the $\mathrm{K}-\mathrm{Pg}$ boundary in each of these studies. With the $\mathrm{K}-\mathrm{Pg}$ boundary isotopic excursion indistinguishable from what stratigraphically precedes and succeeds it, it can hardly form the basis of a robust, practical chemostratigraphy.

\section{6. $K-P g$ Paleoenvronmental Summary}

Taken altogether, these are exceptional - if not immediately conclusive - stratigraphic data, and we pause for a moment to consider their paleoenvironmental significance. They might indicate a multi-thousand year transitional environment as proposed by Sprain et al. (2015); but the evidence is clear at that time that the landscapes were not just flooded, but that there was active erosion and redeposition, and thus the "Z-coal" at one topographic level might not be expected to be of the same age as the "Z-coal" at the same topographic level elsewhere, in another locality. The concept of a "Z-coal complex" - if we must adhere to the "Z-coal" terminology - is a reasonable one; and our view is that extensive flooding began essentially isochonously across the Hell Creek coastal plain as it is exposed in eastern Montana and western North Dakota, resulting in the peat mires and silty, swampy deposits that characterize the earliest Paleogene of this region.

The imprecision of pollen dating precludes decimeter - scale precision when identifying the K-Pg boundary, and the variation in tephra dates suggests that some of the oldest tephras may have been eroded. This would give the appearance of a diachronous $\mathrm{K}-\mathrm{Pg}$ 
boundary when in fact none exists. With this stratigraphic uncertainty, two mutually exclusive scenarios are possible: a "ponding" scenario and a "flooding" scenario.

\subsubsection{Early Paleogene ponding}

The ponding scenario involves conventional causes: extensive ponding could certainly have been caused by the coeval transgression of the Paleocene Cannonball Seaway, adumbrations of which are seen in the intercalated marine Breien Member and Cantapeta Tongue. A rapid rise in sea level would cause broadly contemporaneous flooding over the extensive, topographically muted coastal plain. Other more dramatic events, associated with the asteroid impact, may have contributed to the abundance of water (see below), but the most obvious and explicable cause is sea-level rise. The low topography of the coastal plain would produce geologically instantaneous ponds and swamps over the region circumscribed by the HCF outcrop belt along the Little Missouri river to the east, and the Fort Peck Reservoir to the west.

\subsubsection{Early Paleogene flooding}

In the second scenario, the "ponding" described by Fastovsky (1987) might better be characterized as flooding; the emphasis thus shifts from gradual to catastrophic. Fastovsky et al. (2008) and Grandpre et al. (2008), building upon an idea of P.M. Sheehan, proposed that the extensive flooding observed in the $\mathrm{K}-\mathrm{Pg}$ coastal lowlands of the Western Interior could be attributed to upland landscape denudation resulting from deforestation caused by continental wildfires (Wolbach et al., 1985; 1988; see also Robertson et al., 2013a) started by an intense infrared radiation pulse and from fallout, both results of the Chicxulub asteroid impact (Robertson et al., 2004; 2013a). They analogized these environmental affects with those of nineteenth- and twentieth-century mining activities in California, in which denuded upland 
forests destabilized and eroded upland landscapes, and caused significant downstream flooding and rapid sediment accumulation in the Central Valley (e.g., Florsheim and Mount, 2003).

Critical in this idea is the recognition that the "ponding" observed at the lithostratigraphic boundary is remarkable, anomalous and pervasive. Aside from the observation that throughout the Williston Basin, this lithostratigraphic contact is characterized by flooded landscapes - a fact that undoubtedly contributes to the rarity of earliest Paleocene terrestrial fossil vertebrates - the same paleoenvironmental sequence can be observed in the adjacent Denver Basin as well (K.R. Johnson, personal communication, 10/2007). In this view, the HCF - Fort Union facies change records a regional heretofore unappreciated paleoenvironmental catastrophe.

\section{Hell Creek Floras}

The HCF preserves a rich and varied flora. Plants are represented by diverse and important macroflora in the form of fossil leaves (plant compressions, Fig. 6A and B, see below), comminuted plant debris, and as impressions, generally preserved in ironstonereplaced deposits. Seeds and cones are also found preserved via other means, such as 3D casts and molds, and ironstone replacement (Fig. 6C and D). Fossil wood is also commonly found in the $\mathrm{HCF}$ as white silicified, permineralized fragments (Fig. 6E). Charcoal is also common, preserved as macroscopic pieces (Fig. 6F), or visible as microscopic fragments in palynofacies (Fig. 6G). These charcoal fragments have been interpreted to suggest that wildfires were relatively common in the Hell Creek ecosystems (Brown et al., 2012; Bamforth et al., 2014).

Most facies of the HCF and overlying Fort Union Formation contain very diverse pollen and spore assemblages (Fig. 6G). Indeed, the vast majority of studies and data revolve around pollen and spores, and plant compressions. 


\subsection{Pollen and spores}

\subsubsection{Introduction}

The study of pollen and spores has played a very important role in the identification of the K-Pg boundary in the HCF. Its use allows for the generation of very high-resolution datasets $(<1 \mathrm{~cm}$ sampling resolution), which can be used to closely track the evolution of plant communities. As noted above, in the $\mathrm{HCF}$, palynology has been key in identifying the position of the K-Pg boundary, especially at localities where indicators of the Chicxulub impact are not preserved.

Palynologists were the first scientists to recognize that a major, abrupt change occurred at the K-Pg boundary (Norton and Hall, 1969; Oltz, 1969; Leffingwell, 1970; Tschudy, 1970, 1984), a change now known to take place globally (Bercovici et al., 2012a; Vajda and Bercovici, 2012, 2014). They observed that the abrupt disappearance of many pollen species in the Western Interior coincided with the lowest coal formulation (Collier and Knechtel, 1939; Brown, 1952; see above). Moreover, the disappearance of the many pollen species was shown to be stratigraphically coincident with the markers of the impact in the HCF (Tschudy et al., 1984; Hotton, 1988, 2002; Bohor et al., 1984, 1987a, b; Smit and van der Kaars, 1984; Smit et al., 1987; Sweet et al., 1999; Nichols, 2002, 2007; Nichols and Johnson, 2002), the rest of the North American Western Interior (Orth et al., 1981; Pillmore et al., 1984; Nichols et al., 1986; Jerzykiewicz and Sweet, 1986; Lerbekmo et al., 1987; Bohor et al., 1987a; Nichols, 1990; Nichols and Fleming, 1990; Sweet et al., 1990, 1999; Wolfe, 1991; Nichols et al., 1992a; Sweet and Braman, 1992) and worldwide (Saito et al., 1986; Brinkhuis and Schiøler, 1996; Vajda et al., 2001, 2004; Vajda and Raine, 2003; Willumsen and Vajda, 2010). 
It is now evident that virtually all facies present in the HCF, including coarse sandstones, yield pollen and spore assemblages that can be identified and studied (Hotton, 2002; Bercovici et al., 2009, Vajda et al., 2013). This is one of the strengths of the HCF; however, the study of these assemblages must be tightly coupled with detailed lithological and sedimentological context, because different taphonomic processes operate in different depositional environments (e.g., see below).

The latest Maastrichtian is divided into four main palynological provinces defined by the restricted geographic occurrence of specific species of pollen (Herngreen and Chlonova, 1981; Herngreen et al., 1996; Vajda and Bercovici, 2014). Because the entire Western Interior of North America is contained within the Aquilapollenites province, comparison of the palynological record there is facilitated.

Palynomorphs that go extinct at the K-Pg boundary have been termed "K-taxa" (Nichols, 2002) or "K species" (Hotton, 2002). Because the majority of K-taxa are very distinctively shaped, the recognition their absence from palynological assemblages is generally straightforward, contributing to the speed and precision with which the $\mathrm{K}-\mathrm{Pg}$ boundary can be recognized in the HCF.

\subsubsection{Hell Creek palynoflora}

The HCF pollen and spore flora is very diverse and represented by over 115 taxa in southwestern North Dakota (Nichols, 2002), and over 281 taxa in Eastern Montana (Hotton, 2002), not including fungal spores and algal cysts, which are also present. These rich palynofloras belong to the Wodehouseia spinata Assemblage Zone as defined by Nichols (1994), characterized by the first appearance of the angiosperm species Wodehouseia spinata at the base of the upper Maastrichtian. 
The Hell Creek palynoflora reflects a lush, subtropical to warm-temperate evergreen forest dominated by angiosperms (flowering plants), ferns, and, to a lesser extent, various gymnosperms. The understory vegetation of the Hell Creek was represented by many hydrophilous ground-dwelling plants including lycopods (clubmosses) represented by large trilete spores. Other understory floras include spikemosses and quillworts (Isoetes), hornworts (Anthocerotales) liverworts (Marchantiales), and bryophytes (sphagnum moss). (Nichols, 2002; Hotton, 2002; Bercovici et al., 2009).

Filicales, or true ferns, are represented by many spore types, and generally populate Hell Creek palynological assemblages with an average of $\sim 50 \%$ (min: $\sim 20 \%$, max: $\sim 80 \%$, Bercovici et al., 2009). Most of the understory vegetation was probably dominated by ferns (Nichols, 2002; Vajda et al., 2013). Heterosporous aquatic fern spores are also present, including those aquatic ferns that formed free-floating mats on the surface of bodies of open water. Shrubby gymnosperms are represented, and along with other shrubby plants such as cycads, which had mostly replaced benettites by the end of the Cretaceous (Nichols and Johnson, 2008).

The Hell Creek canopy was comprised of evergreen needle conifers. Other conifers of the Pinaceae (pine family) were present as well, and bisaccate pollen grains with large sacci (Podocarpidites sp.) suggest the presence of podocarps, a group today mainly endemic in the Southern Hemisphere.

Angiosperms are, together with ferns, the most abundant palynomorphs found in the HCF, however angiosperms are more diverse than any other palynomorph group. This observation corroborates the overwhelming diversity in angiosperm leaves seen in macrofloral assemblages from the HCF (see below). Angiosperms likely occupied various habitats, from understory vegetation to the canopy. They included monocots such as Arecaceae (palms), Pandanus, and various other freshwater aquatic species. Woody dicots 
represented most of the diversity recorded, albeit the botanical affinity of many species found in the HCF remains uncertain (Nichols, 2002; Hotton, 2002; Bercovici, 2009).

Other relict plant groups may be present, like Cheirolepidiaceae, Pteridosperm and Caytoniales (Vajda et al., 2013). Contrary to many Cretaceous ecosystems earlier than the $\mathrm{HCF}$, Araucariaceae were very marginal components of the flora if present at all (Johnson, 2002).

Other common, non-pollen palynomorphs are represented by a wide diversity of fungal spores (Nichols and Johnson, 2008; Bercovici et al., 2009). Freshwater algal cysts are also diversely represented, suggest the presence of ponds in the HCF (Nichols, 2002; Bercovici et al., 2009).

Although the Hell Creek palynoflora is nearly monotonic as regards floral diversity, Nichols (2002) proposed five provisional subzones of the Wodehouseia spinata Assemblage Zone in Southwestern North Dakota. These subzones, from A to E (bottom of the HCF to top), are defined by the stratigraphic range of ten species of angiosperms characteristic of the Cretaceous (Fig. 7). From these subzones, a clear distinction can be made between the lower $40 \mathrm{~m}$ of the HCF, and the upper $60 \mathrm{~m}$. The topmost $5 \mathrm{~m}$ ("Subzone E") stand out, characterized by the occurrence of two taxa (Nichols, 2002).

In contrast to this, Arens et al. (2014) interpreted a K-Pg boundary from Bug Creek (McCone County, Montana) as showing a decrease in diversity in the last $\sim 1.5 \mathrm{~m}$ of Hell Creek deposits leading up to the K-Pg boundary. The authors propose that a diminution in pollen species richness was underway prior to the K-Pg boundary extinction event, indicating increasing heterogeneity of the latest Cretaceous vegetation and resulting from a "press" type disturbance (see the press/pulse extinction model, below).

However, the depositional environment from which these palynological assemblages were retrieved requires consideration. Arens et al. (2014) report that these assemblages were 
recovered from rooted mudstones with slickensides indicating a gleyed paleosol, a facies common throughout the Hell Creek (Fastovsky and McSweeney, 1987; Bercovici et al., 2008; 2012b; Vajda and Bercovici, 2014). Poor pollen preservation and recovery of palynological assemblage is typical of gleyed paleosols and has been observed repeatedly within the HCF, independent of the K-Pg boundary (Hotton, 2002; Bercovici et al., 2009). That the apparent decrease in diversity reported by Arens et al. (2014) is a facies-controlled preservational artifact cannot be ruled out.

\subsection{3. $K$-taxa and the $K-P g$ extinction}

The biggest change observed in the composition of HCF palynological assemblages occurs at the $\mathrm{K}-\mathrm{Pg}$ boundary, which is marked by the disappearance of many pollen taxa. Unlike the Permian-Triassic and Triassic-Jurassic boundaries (Vajda and Bercovici, 2014), the palynologically defined K-Pg boundary is based on the extinction of Cretaceous taxa rather than the appearance of Paleocene taxa (Hotton, 1988; 2002; Nichols, 2002). Furthermore, the pattern of the disappearances of pollen taxa is independent of paleoenvironment (Nichols and Fleming, 1990).

Collectively, K-taxa are present in the uppermost part of the HCF with an average relative abundance of $\sim 15 \%$ (min: $\sim 5 \%$, max: 50\%, Bercovici et al., 2009). The synchronous disappearance of K-taxa is part of the compelling evidence for an abrupt and continent-wide devastation of plant communities at the K-Pg boundary. Extinction at the taxonomic level is estimated to be $\sim 30 \%$ in southwestern North Dakota (Nichols, 2002).

Certain factors, however, complicate the precise identification of the $\mathrm{K}-\mathrm{Pg}$ boundary. Historically the K-Pg boundary was identified by the highest stratigraphic occurrence of Ktaxa in a sample series (Nichols and Johnson, 2002). However, K-taxa can decline in abundance before the K-Pg boundary possibly due to the Signor-Lipps (1982) effect (Nichols 
and Johnson, 2002), or because of facies-related bias (Kroeger, 2002; Bercovici et al., 2009; Vajda and Bercovici, 2014). Moreover, they can persist in very low numbers into the earliest Paleocene (Nichols and Johnson, 2002; Bercovici et al., 2009, 2012b; Vajda and Bercovici, 2014), such as occurs in Woodhouseia spinata (Nichols, 2002; Bercovici et al., 2009, 2012a). Of the 14 species of Aquilapollenites found in the $\mathrm{HCF}$, only one crosses the $\mathrm{K}-\mathrm{Pg}$ boundary (Nichols, 2002), and like other boundary-crossing K-taxa, it persists in low abundance in the Paleocene for very short durations (Bercovici et al., 2009, 2012a, b).

As a result, however, presence/absence data overestimate the placement of the $\mathrm{K}-\mathrm{Pg}$ boundary, indicating a younger boundary than would be obtained geochronologically. Recently, therefore, to get a more reliable estimation for the placement of the K-Pg boundary, the last major drop in K-taxa relative abundance without subsequent recovery has been used (Bercovici et al., 2009). Generally, this involves a drop in relative abundance of two orders of magnitude, down to $0.5 \%$ or less, compared to values commonly found in the HCF. This palynostratigraphic method for identifying the K-Pg boundary has generally been reliable, and in southwestern North Dakota, where independent geochemical markers of the impact are present, synchroneity between the extinction and the geochemical markers has been demonstrated at three localities, Pyramid Butte (Fig. 5A and B), Mud Buttes (Fig. 5C and D) (see Nichols and Johnson, 2002) and John's Nose (Fig. 5E and F, Bercovici et al., 2012b).

Because the majority of K-taxa are represented by pollen grains with a thick and structurally complex exine, Sweet and Braman (2001) proposed that these could be attributed to zoophilous (more especially entomophilous, or insect pollinated) taxa, indicating a possible relationship with the extinction of insects at the K-Pg boundary (Rehan et al., 2013).

\subsubsection{Fern spike}


A distinctive feature, intimately associated with the K-Pg boundary globally, is the socalled "fern spike" of Fleming and Nichols (1990) (see also Wolfe, 1991). It consists of a monospecific assemblage of ferns, peaking at $60-80 \%$ of the assemblage, and occurring in an extremely limited stratigraphic zone, generally $\sim 1 \mathrm{~cm}$ thick, exclusively at localities where the $\mathrm{K}-\mathrm{Pg}$ boundary clay complex or the iridium anomaly is present. In fact, the fern spike is actually represented by two individual events (Vajda and Bercovici, 2014).

Since its original discovery in association with the K-Pg boundary (Orth et al., 1981; Tschudy et al., 1984), the fern spike has generally been interpreted as an indication of plant cover devastation (Fleming and Nichols, 1988, 1990; Wolfe, 1991; Sweet et al., 1999; Sweet and Braman, 2001; Vajda et al., 2001, 2004; Vajda and McLoughlin, 2004, 2007; Vajda and Bercovici, 2014). Ferns are pioneer re-colonizers of devastated landscapes, and are classic examples of so-called "disaster floras"; non-climax floras that initially colonize highly disturbed landscapes. More recent examples of "fern spikes" include the localized early recolonization of the denuded ground by ferns after the massive landslides induced by the 1980 eruption of Mount St. Helens, or the short-lived dominance of ferns in the Krakatau floras following the 1883 eruption (Tschudy et al., 1984). In a similar way, ferns are the first colonizers of freshly deposited lava flows in Hawaii, a biotic response to destabilized landscapes.

\subsubsection{Paleocene recovery of pollen}

While the changes observed at the K-Pg within palynological assemblages are drastic and abrupt, the earliest Paleocene flora does not give the sense of an entirely new world. Since the extinction involved 33 pollen taxa ( $30 \%$ of the species), the immediate recovery involved the surviving $\sim 70 \%$, boundary crossers. Ultimately, the earliest Paleocene palynoflora is less diverse than the Hell Creek palynoflora, and assemblages have a tendency 
of being dominated by but a few pollen species (see Fig. 18 in Bercovici et al., 2009). New Paleocene-restricted species such as Momipites inaequalis appear; however, these new Paleocene taxa remain relatively rare and hard to identify (Nichols, 2003; Braman and Sweet, 2012; Bercovici et al., 2012b; Vajda and Bercovici, 2014).

A 0.5-1 m interval of a dark grey, organic rich mudstone sequence occurring above the K-Pg boundary in southwestern North Dakota beautifully preserves the very high abundance of the aquatic plants, emblematic of the first stages of the recovery of terrestrial plant communities in the earliest Paleocene (Bercovici et al., 2009). It contains abundant pollen taxa that are uncommon in the HCF (Hotton, 2002; Nichols, 2002; Bercovici et al., 2009). These later taxa collectively indicate a wetter environment with significant standing water, an observation in agreement with the sedimentological evidence suggesting ubiquitous earliest Paleocene flooding.

\subsection{Macroflora}

\subsubsection{Introduction}

Throughout the Phanerozoic, only two major events involving global plant communities stand out: The demise of coal-swamp forest communities during the Permian with loss of whole plant families at the Permian-Triassic boundary (Sahney et al., 2010; Cleal et al., 2012 and references therein), and the rise to dominance of angiosperms during the Early Cretaceous (Taylor et al., 2009; Friis et al., 2011). Thus, the idea that plant communities did not suffer in the K-Pg mass extinction was firmly anchored amongst paleobotanists (Hickey, 1981; Traverse, 1988; McElwain and Punyasena, 2007). No loss of higher taxa is recorded, and angiosperm-dominated plant communities of the Cretaceous have similar compositions to angiosperm dominated plant communities of the earliest Paleogene, an observation that still 
stands out when looking at datasets at large, with coarse stratigraphic and taxonomic resolution (Cascalas-Miñana and Cleal, 2012, 2014).

With the publication of the asteroid impact theory by Alvarez et al. (1980), there was an attempt to reconcile paleobotanical data with an abrupt extinction scenario (Wolfe and Upchurch, 1986, 1987; Wolfe, 1987; Nichols et al., 1992b). But the extraordinary claim called for extraordinary evidence, and existing data, with poor stratigraphic resolution, were not suitable to properly assess the vegetation changes throughout the $\mathrm{HCF}$ and and across the $\mathrm{K}-$ Pg. Thus, L.J. Hickey and K.R. Johnson undertook the collection of new material in southwestern North Dakota. The new plant localities were stratigraphically constrained with unprecedented resolution, and tightly associated with depositional environments (Johnson, 1989, 1992, 2002; Johnson et al., 1989; Johnson and Hickey, 1990).

Fossil plant localities were thought to be rare in the Hell Creek, because while animal fossils are usually found by prospecting on eroded surfaces, fossil plant compressions are destroyed by erosion. Finding plant localities required locating productive sedimentary facies such as laminated siltstones and sandstones. Fresh rocks that might preserve plant compressions within the laminae were then quarried. Macrofloral paleobotany in the HCF involves prospecting by pickaxe.

\subsubsection{Hell Creek macroflora}

The rich macrofloral record leading up to the $\mathrm{K}-\mathrm{Pg}$ boundary has been extensively sampled and documented in North Dakota (Johnson et al., 1989; Johnson and Hickey, 1990; Johnson, 2002; Wilf and Johnson, 2004) and shows very diverse assemblages of rainforest type plants, largely dominated by angiosperms including palms, associated with several ferns, conifers, and single species of cycads and Ginkgo (Johnson, 2002). The taxonomic diversity is comparable to that of the palynological assemblages, but the relative abundances differ 
significantly, as Hell Creek macrofloral assemblages are overwhelmingly dominated by angiosperms (dicots, $>90 \%$ ). Multiple sites with a very high abundance of leaf specimens, with diversities exceeding $>100$ species per sites, were reported from different terrestrial depositional settings of the HCF, including flood plains, ponds, crevasse splays and levees, or within channels (Johnson, 2002).

Successive macrofloral changes are clearly visible within the HCF, and Johnson and Hickey (1990) recognized three distinctive assemblages (Fig. 7), subsequently revised by Johnson (2002). The HCIII assemblage, the youngest macrofloral zone of the HCF, is significantly more diverse compared to the underlying $\mathrm{HCI}$ and to a lesser extent, to the HCII assemblages (Fig. 7). A few meters below the K-Pg boundary, sites have yielded extremely diverse floras, among the richest taxonomic diversity known from any Cretaceous fossil plant localities in the world (Johnson, 2002). The higher taxonomic diversity observed in the HCIII zone is correlated to an episode of warming as indicated by temperature proxies using leaf margin analysis (CLAMP, Wilf et al, 2003; Wilf and Johnson, 2004; see Fig. 7).

\subsubsection{The $K-P g$ boundary}

As seen in the palynological record, a major change in flora diversity and composition is observed, coincident with the K-Pg boundary (Johnson, 2002; Wilf and Johnson, 2004; Blonder et al., 2014; see Fig. 7). The extinction level is however much higher than recorded from pollen and spores, with $57 \%$ of the Hell Creek species disappearing at the K-Pg boundary (the figure of $57 \%$ corresponds to the flora recorded in the last $5 \mathrm{~m}$ of the Hell Creek; considering the entire HCF, this figure jumps to $78 \%$ extinction [Johnson, 2002]). Major changes in flora diversity is also observed coincident with the $\mathrm{K}-\mathrm{Pg}$ boundary in the Denver Basin (Barclay et al., 2003; Barclay and Johnson, 2004). Temperature proxies indicate a drastic and very abrupt temperature drop at the K-Pg boundary (Wilf et al, 2003; Wilf and 
Johnson, 2004), which is also corroborated by marine plankton (Brinkhuis et al., 1998; Vellekoop et al., 2014).

\subsubsection{Paleocene recovery}

Despite the striking loss of plant species at the K-Pg boundary, many plant localities exist in the Fort Union Formation, less than a meter above the boundary (Bercovici et al., 2008). The earliest Paleogene recovery floras are characterized by a low-diversity assemblage dominated by dicots, and usually represented by 3-4 species plus several other rare taxa. This low-diversity recovery macrofloral assemblage was coined FUI by Johnson (2002). The FUI and other time-equivalent assemblages (Peppe et al., 2009; Peppe, 2010) are composed of taxa that survived the mass extinction event, yet, were only marginal components of the $\mathrm{HCF}$ floral assemblages, generally most common in mire facies (Johnson, 2002). This survival pattern may therefore represent the existence of an important local ecological filter in the recovery process. The first occurrence of a characteristic Paleocene taxon is that of Paranymphaea crassifolia, which is recorded a few meters above the K-Pg boundary (Johnson, 2002; Bercovici et al., 2008).

\subsection{Plant-insect interactions}

Despite the existence of laminated and fine grained sedimentary rocks, insect body fossils from the $\mathrm{HCF}$ are exceedingly rare. Clear or frosted orange amber is relatively common in carbonaceous shales and lignite deposits of the HCF, but usually without any macroscopic inclusions. However, a potential amber-producing locality from the HCF in Harding County, South Dakota, could shed light on insect diversity by the mean of threedimensionally preserved insect body fossils (DePalma et al., 2015). 
The largest evidence of Hell Creek insect life to date comes from trace fossils, i.e., insect-mediated damages on leaves (Fig. 6H), and provides an outstanding opportunity to assess the diversity and changes in insect communities through time during the deposition of the HCF and across the K-Pg boundary (Labandeira et al., 2002a). Based on the immense collection of plant fossils from southwestern North Dakota, a total of 51 specific plant-insect associations was identified, including traces left by hole and margin feeders, mining and galling insect, and other types of traces on leaves such as skeletonization. Because many insects target specific plants species (so called specialized interactions), insect-mediated damages can represent a good proxy of insect diversity (Labandeira and Currano, 2013; Carvalho et al., 2014).

Following the trend observed in the macroflora, the diversity of insect-mediated damages varies throughout the $\mathrm{HCF}$, with a slight increase in diversity associated to the equally more diverse HCIII plant assemblage (Labandeira et al., 2002a; see Fig. 7). This slight increase in diversity coincides with the episode of warming recorded at the very end of the Maastrichtian (Wilf et al, 2003; Wilf and Johnson, 2004).

Like so many other taxa, insect diversity undergoes a major change at the $\mathrm{K}-\mathrm{Pg}$ boundary, where insect-mediated damages on leaves show a drastic reduction in diversity (Fig. 7), affecting specialized types of interactions, while the generalized interactions were mostly spared (Labandeira et al., 2002a, b; Wilf et al., 2006; Donovan et al., 2014). The possible scenario for this observation is that insects were directly affected by the adverse changes in climatic conditions associated with the aftermath of the Chicxulub impact (primary extinction), and/or that insects were affected by the demise of their plant-host (secondary extinction, (Labandeira et al., 2002a, b). This scenario matches the hypothesis of Sweet and Braman (2001), regarding plants, namely, that insect-pollinated taxa were more prone to 
extinction, indicating cascading reactions within a complex network of interactions in Hell Creek ecosystems.

The insect extinction recorded in the HCF parallels that of the plant extinction, in which while higher groups remained extant, significant extinction within those higher groups is recorded. We have noted this claim (above) for plants (Cascalas-Miñana and Cleal, 2014) and a similar claim has been made for insects: that the only mass extinction suffered by insects occurred at the Permo-Triassic boundary (Erwin, 2006). The rigid adherence to higher taxonomic diversity as a measure of the magnitude of an extinction, we feel, has the potential to cause significant ecological disruption to be overlooked.

\section{Hell Creek Vertebrate Faunas}

A variety of $\mathrm{K}-\mathrm{Pg}$ faunal analyses has been carried out in the $\mathrm{HCF}$; most were restricted to particular groups; a rare few took on the entire Hell Creek fauna. Perhaps the most often cited is the study by Archibald and Bryant (1990; also discussed in Archibald, 1996), who used presence/absence data between the Hell Creek and Fort Union to identify survivorship patterns in vertebrates. These same data were reviewed by Sheehan and Fastovsky (1992); while the quantitative details of their respective conclusions varied, both sets of authors ultimately concluded survivorship across the K-Pg boundary in the North American upper Great Plains was strongly promoted by aquatic habitat. Archibald (1993; 1996) attributed the aquatic survivorship patterns he reported to habitat fragmentation;

Sheehan and Fastovsky (1992) attributed these patterns to the effects of an asteroid impact.

The habitat fragmentation model of Archibald (1996; 2011; see also Archibald and Fastovsky, 2004) proposes that as the seas receded, fluvial downcutting Hell Creek landscapes produced fragmented habitats, ultimately contributing to the dinosaur extinction. In fact, there has been no physical evidence reported for fragmented habitats, such as deeply 
incised fluvial channels (Sheehan and Fastovsky, 1993); moreover, as noted by Johnson et al. (2002), evidence now suggests that regression maximum preceded HCF deposition, and that the HFC was deposited during a transgressive phase of the Cannonball Sea. By contrast, Sheehan and Fastovsky (1992) noted that aquatic environments might constitute refugia against environmental perturbations caused by the asteroid; moreover, aquatic organisms tend to function in detritus-based food chains, which would have served as a buffer against the drop in primary production (plant extinction; see above) that characterized the terrestrial realm.

\subsection{Dinosaurs}

Non-avian dinosaurs (hereafter, dinosaurs) are of course icons for the K-Pg extinction, and the HCF has a truly remarkable and diverse record of latest Cretaceous dinosaur material (e.g., Weishampel et al., 2004). This fossil record in the context of the K-Pg extinction has been reviewed by Fastovsky and Sheehan (2005), and will be but briefly summarized here. In short, while qualitative descriptions have historically proposed a decrease in number and diversity of dinosaurs going through the formation (e.g., Dodson, 1996; but see Russell, 1982), quantitative studies - both field-based (Sheehan et al., 1991; Pearson et al., 2001, 2002) and theoretical (Wang and Dodson, 2006) - suggest that there is no empirical evidence for a diminution in either dinosaur abundance or diversity.

The field-based studies all involved multi-year dinosaur censuses in stratigraphically equivalent bins, and then statistically testing, using rarefaction, for differences among the bins. The methods used by Sheehan et al. (1991) were criticized by Hurlbert and Archibald (1995); however, Pearson et al. (2002) subsequently reaffirmed the results of Sheehan et al. (1991) with a larger database in a more refined stratigraphic context (Fig. 7). 
Supporting the qualitative idea that dinosaurs were on their way out of existence before the K-Pg boundary were claims of a "3 m gap" between the highest dinosaur and the K-Pg boundary, as recognized by the HCF-Fort Union formational contact (Clemens and Archibald, 1980; Williams, 1994, Archibald, 1996; Sarjeant, 1996; MacLeod et al., 1997). This assertion was used to suggest that the dinosaur extinction predated the asteroid impact. However, the validity of the "3 m gap" has been repeatedly shown to be spurious, on theoretical grounds (Signor and Lipps, 1982; Alvarez, 1983) and on empirical grounds (Retallack et al., 1987; Sheehan et al., 2000; Lyson et al., 2011a).

Changes in the disparity of global dinosaur populations were used by Brusatte et al. (2012) as proxies for "breadth of functional and ecological behavior (Brusatte et al., 2012, p. 2), as indicators of the nature of the dinosaur extinction. While the study was global in scope, Hell Creek dinosaurs obviously contributed important - in many cases, key - Maastrichtian data. In this study, Campanian "bins" were compared with Maastrichtian "bins", and the changes assessed. No uniform pattern resulted from this work; the study was inconclusive as regards documentation of long-term functional or ecological trends.

As regards avian dinosaurs, a very spotty record has largely hindered definitive conclusions about this group. Nonetheless, considerable evidence now has accumulated to suggest that the antecedents of modern bird groups appeared during Cretaceous time (Cracraft and Clark, 2001; Clarke et al., 2005), whether or not they underwent a major Cretaceous radiation. Longrich et al. (2011) identified 17 species of Maastrichtian birds, based upon data from the HCF and two others from the North American western interior, of which 7 species belonging to archaic groups - Enantiornithes, Hesperornithes, Ichthyornithes, and Palintropiformes - persisted within an estimated 300,000 years of the K-Pg boundary, and then went extinct. As reported by these authors, therefore, birds underwent a $41 \%$ extinction.

\subsection{Testudines}


Turtles are abundant and diverse members of HCF vertebrate faunas, consisting of 8 families of turtles represented by at least 19 genera (Holroyd and Hutchinson, 2002). They occupied an array of largely aquatic niches. By all accounts, turtles appear to have had an untroubled K-Pg boundary experience; Hutchinson and Archibald (1989), Pearson et al. (2002), Lyson and Joyce (2009), Lyson et al. (2011b), and Holroyd et al. (2014), all report no significant extinctions in turtle faunas across the K-Pg boundary.

Turtles and crocodiles (Pearson et al., 2002) epitomize the marked survivorship of aquatic faunas across the K-Pg boundary, attributed by both Archibald (1996) and Sheehan and Fastovsky (1992) to their habitats as aquatic refugia: the former proposed that lowered sea level and lengthening streams favored them as opposed to the dinosaur victims of habitat fragmentation; the latter conceived of aquatic settings as refugia against intensive environmental perturbations caused by the asteroid, as well by the precipitous drop in primary productivity.

\subsection{Microvertebrates}

The HCF has an extraordinarily rich, justifiably famous microvertebrate record. Most prominently represented in this record are lissamphibians, squamates, a variety of elasmobranchs (sharks, skates, and rays), Actinopterygii (ray-finned bony fish), and mammals (though they are commonly preserved as microvertebrates, we group birds - avian dinosaurs with non-avian dinosaurs above). From the 1960 s to the mid 1980s, R.E. Sloan and a variety of students and colleagues, including L. Van Valen and J.K. Rigby, Jr., generated extensive microvertebrate collections via screen washing in Montana exposures of the HCF. From the late 1960 s to the present, W.A. Clemens, and a variety of his students and colleagues continued to screen wash and study important microvertebrate localities in the region. Much of this history is detailed in Clemens and Hartman (2014). 
Readers are commended to Estes et al. (1969) for a general summary of his early, important contributions to HCF microvertebrate (especially squamate) paleoecology. A later study (Bryant, 1989), describes the extensive collections made up to that date by W.A. Clemens and his associates, and served as the basis for subsequent quantitative work (e.g., Archibald and Bryant, 1990).

By contrast, microvertebrates from North Dakota have only been studied in since the early 1980s, largely through the collecting efforts of D.A. Pearson and a group of dedicated volunteers at the Pioneer Trails Regional Museum in Bowman, ND. Pearson and colleagues' collections form the basis for the landmark K-Pg study described in Pearson et al. (2002; above). More recently, microvertebrate collection in the region has been undertaken by $\mathrm{T}$. Lyson, in association with the non-profit Marmarth Research Foundation.

\subsubsection{Elasmobranchi and Actinopterygii}

Fish (sensu lato) have been recently studied in the HCF by a number of workers, including Hoganson and Murphy (2002), Cook et al. (2014), and Brinkman et al. (2014). Cvancara and Hoganson (1993) and Hoganson and Murphy (2002) noted dissimilarities between Fox Hills elasmobranchs and those of the Cannonball Member of the Fort Union, and suggested that the K-Pg extinction must have significantly affected shallow water faunas in the Western Interior Sea. Cook et al. (2014) and Brinkman et al. (2014) reconstructed the paleoecology of HCF elasmobranch and actinopterygian faunas (respectively), in the process redescribing and revising some taxa. While in the case of Brinkman et al. (2014), the Hell Creek was reconstructed as more teleost-rich than previously thought, in both of these latter two studies, the nature of the $\mathrm{K}-\mathrm{Pg}$ extinction as reflected in these faunas was not addressed.

5.3.2. Lepidosauria and non-dinosaurian archosaurs. 
The comprehensive, quantitative study of Pearson et al. (2002) included microvertebrates from North Dakota. They concluded that there was no discernible change in the pattern of diversity of all vertebrates - including microvertebrates - through the thickness of the HCF. Along with the groups discussed here, this applied to the diapsid, amphibious crocodilians and champsosaurs (Choristodera).

Longrich et al. (2013) studied the K-Pg North American squamate record (a transect of data running from New Mexico, USA, to Alberta, Canada), supported in large part - but certainly not exclusively - by fossils from the HFC. They recorded an $83 \%$ drop in the number of species across the K-Pg boundary. Unfortunately, the Hell Creek part of the database in this study is only constrained to "Lancian," a NALMA that, in the HCF, is likely restricted to the final $\sim 1.5$ million years of the Maastrichtian.

\subsubsection{Lissamphibia (living Amphibia)}

While both Archibald and Bryant (1990) and Pearson et al. (2002) addressed amphibians as part of their larger studies, Wilson et al. (2014b) carried out a focused stratigraphically controlled study of caudates (salamanders) and allocaudates (salamander-like lissamphibians) diversity and evenness through the thickness of the HCF. The study was large; it was based upon 2021 specimens covering a time range from 67.5 - 65.3 Ma. The groups showed stability in the lower HCF; however, following a diversity maximum in the middle region of the formation, diversity declined through the last third of the formation. Wilson et al. (2014b) interpreted their results as supporting a "complex, multi-caus(al)" mass extinction scenario (see below).

\subsubsection{Mammalia}


The Mesozoic mammals preserved as microvertebrate fossils in the HCF are what initially drew many academic paleontologists to the region, and the fortunes of mammals across the K-Pg boundary there have become something of a lightning rod for a variety of opinions about the magnitude and timing of the extinction. Mesozoic mammals are of particular interest and value, because of their rarity (but, in the case of the HCF, relative abundance), diversity, identifiable morphologies, relatively high preservation potential, and their amenability to quantitative analyses. It is far beyond the scope of this paper to cover the extraordinarily extensive $\mathrm{K}-\mathrm{Pg}$ fossil mammal literature completely; here we simply touch on a few highlights, particularly those that pertain to HCF mammals in the context of the $\mathrm{K}-\mathrm{Pg}$ extinction.

Van Valen (1978) and Van Valen and Sloan (1977) identified fluxes in mammalian taxa suggesting that, preceding the $\mathrm{K}-\mathrm{Pg}$ boundary, there was a gradual transition from metatherian and multituberculate-dominated faunas to eutherian-dominated faunas (for later expositions of this conclusion, see Archibald, 1996; Hunter, 1999; Hunter and Archibald, 2002). Clemens et al. (1981), in the turbulent wake of the publication of the Alvarez et al. (1980) hypothesis, correctly pointed out that a considerable amount of the requisite stratigraphic data - notably reliable dates and a robust stratigraphy - were not available for the HCF; however, preliminarily, these authors (e.g., Clemens and Archibald, 1980; Clemens et al., 1981) envisioned a complex, multi-faceted transition scenario ${ }^{1}:$ "[We] suggest [that] the Cretaceous-Tertiary transition was a period of several tens of thousands if not hundreds of thousands of years in duration, characterized by interaction of a complex of physical and biological factors producing a high net rate of decrease in biotic diversity within both the terrestrial and marine biotas" (Clemens et al., 1981, p. 297).

\footnotetext{
${ }^{1}$ See also Alvarez, 1983, for insights - albeit harsh ones - into the perspectives of paleontologists at the time, working at the $\mathrm{K}-\mathrm{Pg}$ boundary.
} 
Based upon screen-washed mammal remains (largely teeth), Clemens and Archibald (1980) and Clemens et al. (1981) proposed that the evolution of "riparian" mammal faunas differed from that of "floodplain" faunas, and no overriding event left a single, simplified stamp on these patterns. The transitional view was reiterated and elaborated by Sloan et al. (1986) based upon other data collections from the HCF. At this time, so gradual was this pattern believed to have been, that Archibald (1991) mused, "one might question whether the turnover of non-marine vertebrates in the Western Interior of North America is appropriately termed a mass extinction."

By the time Clemens (2002) penned an extended review of K-Pg mammal evolution, after 22 years and a succession of students ${ }^{2}$ addressing a suite of different aspects of the formation (e.g., geochronology, paleomagnetism, geochemistry, stratigraphy, as well as vertebrate paleontology), this perception of $\mathrm{K}-\mathrm{Pg}$ mammal evolution was broader but in its essentials unchanged. He wrote, "A non-random pattern of survival and extinction of mammals... characterizes faunal evolution across the Cretaceous-Tertiary boundary in northeastern Montana. Paleontological and geological data support hypotheses that a variety of long- and short-term factors influenced the course of vertebrate evolution" (Clemens, 2002, p. 217).

An important addition, however, was the observation that immigrant mammal faunas constitute a significant part of early Paleocene mammal faunas, by way of dramatic contrast with the Cretaceous mammal faunas (Weil and Clemens, 1998; Wilson, 2013), whose antecedents were surely local. This result agrees with Archibald and Bryant (1990), whose data show $100 \%$ mammal extinction in the $\mathrm{HCF}$ at the K-Pg boundary; replacement mammal faunas, evidently, came from somewhere else.

\footnotetext{
${ }^{2}$ A list of these students, many of whom figure in this narrative, includes J.D. Archibald, L. Dingus, D.L. Lofgren, L.J. Bryant, C.C. Swisher, A. Weil, Z. Luo, N.B. Simmons, and G.P. Wilson.
} 
Later studies have continued to add refinement to our understanding of mammalian fluxes across the boundary. Wilson (2005) concluded that the extinction of up to 27 species of mammals "at or near" the K-Pg boundary could not be the work of typical mammalian evolution in the face of climate change. Wilson et al. (2012) have shown that the peak of multituberculate diversity postdates the boundary by $\sim 5 \mathrm{Myr}$, before multituberculates began a precipitous decline towards extinction, some $10 \mathrm{Myr}$ after the $\mathrm{K}-\mathrm{Pg}$ boundary.

A larger, more encompassing study by Wilson et al. (2014b), based upon nearly 5000 mammal specimens, indicates two sequential changes in mammalian faunas, observed $\sim 650$ kyr and 200 kyr before the K-Pg boundary, reconstructed by interpolated sedimentation rates. These changes include decreases in mean body size, faunal turnovers, two first appearances, and a reconfirmation of the general observation that the relative abundance of metatherians decreases. The second series of changes includes a continued decline in the proportion of metatherians represented in the total fauna, and a series of apparent step-wise extinctions, attributed by Wilson et al. (2014b) to either a regional cooling event, or to a Signor-Lipps (1982) sampling artifact. The Wilson et al. conclusion is telling, because it beautifully sums up the problems that have beset reconstructions of faunal fluxes within the HCF:

"What are the implications of these results on $\mathrm{K}-\mathrm{Pg}$ extinction scenarios? On the one hand they show a staggering $75 \%$ local extinction of mammalian species at or very near the $\mathrm{K}-\mathrm{Pg}$ boundary, which... might be interpreted as a single, rapid cause. On the other hand, the results show declining trends in the evenness of mammalian communities and relative abundances of [metatherians] in the $\sim 500-600 \mathrm{kyr}$ [preceding the K-Pg boundary], which may be interpreted as signs of ecological instability brought on by the temporally correlated and possibly causally linked late Maastrichtian event and Deccan volcanism" (Wilson et al. 2014b, p. 384). 


\section{The Hell Creek in Extinction Theories}

\subsection{Introduction}

To date, the coincidence of a full, rich biota, relatively high sedimentation rates, continuous - on geological timescales - deposition across the K-Pg boundary, almost no structural deformation, and a variety of $\mathrm{K}-\mathrm{Pg}$ boundary indicators (iridium and other platinum group metals, shocked quartz, stable isotopes, organic macromolecules, to name but a few), has made the HCF the gold standard for latest Cretaceous events. For this reason, it has been heavily implicated in $\mathrm{K}-\mathrm{Pg}$ extinction theories, going back to the work of Van Valen and Sloan in the 1970s. As we have seen, the Alvarez et al. (1980) hypothesis placed it early on in the forefront the K-Pg "debates" (Glen, 1994), a position that it has not left since.

Ultimately, the HCF cannot show causality; at best it can show coincidence of indicators, and causality is left to be inferred. And, because it is really all about coincidence, the kind of data that can be adduced by the HCF is generally stratigraphic.

\subsection{Single-cause extinction scenario}

Today, the reigning paradigm is the proposition that the $\mathrm{K}-\mathrm{Pg}$ extinction was caused by an asteroid impact, its preeminence agreed upon by both adherents (Schulte et al., 2010) and detractors (Archibald et al., 2010) of the theory. In the HCF, for an asteroid impact to be implicated as the cause of the extinctions, stratigraphic conditions have to be concordant with the predictions of the hypothesis.

If the asteroid is to be implicated as the agent of extinction, what is called for is a geologically instantaneous, synchronous faunal and floral extinction, coincident with the $\mathrm{K}-$ Pg boundary, as identified by the various indicators listed above. In the HCF, Sheehan et al. (1991), Pearson et al. (2002), and Fastovsky and Sheehan (2005) have made this argument 
with regard to dinosaurs (and in the case of Pearson et al., 2002, with other vertebrates as well); Johnson (1992); Nichols and Johnson (2002), Nichols (2002), Hotton (2002), and Bercovici et al. (2009) have made it with regard to the floras. Labandiera et al. (2002) have made it with regard to insects; Cvancara and Hoganson (1993), and Hoganson and Murphy (2002) made it with regard to elasmobranchs. We have discussed some of these data in the preceding sections of this article.

A number of authors have recorded secondary observations, made in the HCF, that are concordant with the hypothesis. In this category, for example, would fall Sheehan and Fastovsky (1992), who interpreted survivorship patterns first described by Archibald and Bryant (1990), as concordant with as asteroid extinction.

\subsection{Multi-cause extinction scenarios}

The current reigning alternatives to the bolide as extinction agent are multi-cause hypotheses, espoused by Archibald (1996; 2011), Archibald and Fastovsky ${ }^{3}$ (2004), the 28 cosignatories to Archibald et al. (2010), Clemens (2002), Clemens et al. (1981), and Wilson et al. (2014b). Although this need not be the case, historically, multi-cause hypotheses have called for a more protracted extinction event or events, the potential causes of which would extend across diachronous timescales. Most recently, the multi-cause hypotheses invoke the following effects: a) marine regression, stream lengthening and "habitat fragmentation;" b) competition; c) climate change, d) volcanism, and e) a coup de grâce by asteroid. A variety of multi-cause hypothesis, the "press-pulse" hypothesis, has been proposed by Arens and West (2008) and Arens et al. (2014).

\footnotetext{
${ }^{3}$ These two authors wrote from conflicting viewpoints, and Fastovsky advocated for the asteroid as the sole cause of the extinction.
} 
Before we discuss the details of multi-cause extinction scenarios, however, we note here that multi-cause hypotheses suffers from a lack of parsimony; every known event during latest Cretaceous times is implicated in some aspect of the extinction (see Archibald and Fastovsky, 2004); the result, from our vantage point, is a kind of dim sum banquet of causes and extinctions. In the following, we very briefly address the various extinctors invoked in multi-cause hypotheses, in the context of the HCF.

\subsubsection{Marine regression}

As we have seen, the argument for a marine regression is flawed; the HCF likely formed under transgressive conditions (Johnson et al., 2002). Archibald (1996; 2011), proposed that the regression caused "habitat fragmentation", in which regression-associated stream lengthening and down-cutting dissected landscapes, diminishing their viability for vertebrates - particularly large ones. Observable physical sedimentological evidence, however, such as progressive changes in parameters like stream width and depth through the HCF, is lacking (Sheehan and Fastovsky, 1993). As noted by Buffetaut (1987), regression can't account for the extinction of even the dinosaurs on any continent, including North America. Finally, an important attribute of the asteroid hypothesis is that it functions in both the marine and terrestrial realms; by contrast, marine regression as it has been proposed has a restricted geographic and taxonomic compass.

\subsubsection{Competition}

The pattern of replacement of metatherians and multituberculates by archaic eutherian mammals, reported by a variety of authors (see above) suggested to some (e.g., Archibald, 1996; 2011; Wilson et al., 2014b) that some of the extinction reflects immigrant competition. In fact, this idea does not accord with the significant mammalian extinctions reported in the 
HCF by Archibald and Bryant (1990) and Wilson et al. (2014b). Competition should involve in-situ ecological transitions; yet, as has been broadly noted by mammalian paleontologists working in the region (Weil and Clemens, 1998; Clemens, 2002; Wilson et al., 2014b), only immigrants eventually populated the post-K-Pg landscapes in the early Paleocene. The pattern appears to reflect the abandonment of these landscapes by endemic mammalian faunas, rather than their gradual replacement (see Wilson et al., 2014b). Finally although there may have been competition from migrating archaic ungulates, this narrow window on North American mammal extinction in the Western Interior hardly explains the wholesale extinction undergone by $\mathrm{K}-\mathrm{Pg}$ global ecosystems. In short, like habitat fragmentation, it is not parsimonious.

\subsubsection{Climate}

Nordt et al. (2003), building upon the work of Keller and Lindinger, 1989, report a very late Cretaceous episode of elevated $\mathrm{pCO}_{2}$ and increased temperatures, identified in both paleosol carbonates from the Big Bend region, Texas (Nordt et al., 2003) and paleofloras (Wilf et al. 2003) coming on the heels of a Maastrichtian general cooling trend (Barrera and Savin, 1999). The climate fluctuation has been linked with Deccan volcanism (India; see below; Self et al., 2006; Chenet et al., 2009; Tobin et al., 2012). Wilf et al. (2003) reconstructed the temperature change as a $5-6^{\circ} \mathrm{C}$ rise (which they acknowledge may be an overestimation) during the $\sim 500 \mathrm{kyr}$ before the $\mathrm{K}-\mathrm{Pg}$ boundary, and precipitously dropping by $\sim 7^{\circ} \mathrm{C} 100 \mathrm{kyr}$ before the $\mathrm{K}-\mathrm{Pg}$ boundary. In any event, there appears to have been some climatic instability during the final half-million years of the Maastrichtian, which Wilson et al. (2014b) have tentatively correlated with the two sequential changes in mammalian fauna composition that they recorded during that time interval. The connection between these shortterm climate changes and other biotic indicators, such as the flora, is to date uncertain. 


\subsubsection{Volcanism}

A coincidence between flood basalts and extinctions has been espoused for some years by V. Courtillot (a popular summary is found in Courtillot, 1995); indeed, a titanic basaltic outpouring has been recorded from the Deccan Traps (see Self et al., 2006; Tobin et al., 2012); the largest pulse of this volcanism has been dated from 250 kyr before the K-Pg boundary to $\sim 750 \mathrm{kyr}$ afterwards (Schoene et al., 2015). The authors note, "Our results are a critical part of this discussion as they are consistent with the hypothesis that environmental and ecological deterioration began with eruption of the Deccan Traps before the Chicxulub impact and the end-Cretaceous mass extinction. Therefore, both the Chicxulub impact and eruption of the Deccan Traps should be considered in any model for the extinction" (Schoene et al., 2015, p. 184).

The hypothesis, as currently proposed, raises several questions. First, the relationship between the intensive volcanism and extinction is not well developed (whereas it is for the asteroid; see Robertson et al., 2004; 2013a, b): it is not clear exactly how this eruption would affect the biota. However, at the Permo-Triassic boundary, in which Siberian Trap volcanism is a likely contender for at least initiating the process of extinction, the suite of geochemical signals and geological markers produced is very different (Ward, 2006; Erwin, 2006; Saunders and Reichow, 2009), with longer term consequences than those observed here. Indeed, it has not been shown that replacing the asteroid with a continental flood basalt event better explains any aspect of the known organic or inorganic record.

Second, if the eruption of the Deccan Traps started $~ 300,000$ years before the K-Pg boundary, this would represent the upper $\sim 22 \mathrm{~m}$ of the HCF using the sedimentation rates of Hicks et al. (2002). Twenty-two m of strata is the entire highest quarter of the HCF, an interval in which, in North Dakota at least, that there is no change recorded in faunal diversity 
(Pearson et al., 2002). Although Wilson et al. (2014b) note some changes in mammal faunas, these do not constitute the kind of wholesale, abrupt (cm-scale) extinction identifiable at the K-Pg boundary in the plant record (Nichols and Johnson, 2002; Hotton, 2002; Bercovici et al., 2009.

Third, while the asteroid impact as a causal agent is supported by a variety of global geochemical indicators, none has been recognized outside of India for the Deccan Traps. By comparison, the Permo-Triassic and Triassic-Jurassic extinctions are marked by a suite of globally distributed features ultimately traced back to magma-derived $\mathrm{pCO}_{2}$ and associated global warming (e.g., Hesselbo et al., 2002; Erwin, 2006; Saunders and Reichow, 2009; Whiteside et al. 2010).

Fourth, we note that, given the abruptness of Deccan volcanism as it has been characterized by Schoene et al. (2015) and the resolution of the fossil record (even in the HCF), extinction by volcanism would be indistinguishable from extinction by asteroid. That is, there is no pattern in the biotic extinction that would allow the effects of volcanism to be teased apart from those of the asteroid. Because of this redundancy, the idea of extinction by volcanism becomes in effect untestable, point alluded to by Brusatte et al. (2014).

Finally, we return to the parsimony argument; the asteroid is a highly plausible agent of extinction, occurring at the right time, with the global reach to do the damage. Why propose another extinction agent, particularly one with so poor - or at best so poorly constrained - a fit to the data?

\subsubsection{Asteroidal coup de grâce.}

Extinction by asteroidal coup de grâce has been codified by the "press-pulse" hypothesis; ecosystems stressed by some factor (perhaps one or more of the four we've listed above?) are "weakened," after which the asteroid delivers the coup de grâce (Arens and West, 
2008). This idea, too, provokes some concerns. First, what, precisely, is a weakened, or stressed ecosystem? Invasive species might disrupt existing trophic relationships, but of course new trophic webs, more attractive to the invaders, would be substituted. Arens et al. (2014) note that in a press setting, "stress-tolerant species replace those intolerant to new conditions" (p. 210). This, however, constitutes a gradual ecological replacement and not an abrupt extinction, and is not in accord with the HCF fossil record. In any event, how does one weaken an ecosystem in terms of its ability to withstand catastrophic, that is to say, very short-term events?

Mitchell et al. (2012) modeled Campanian and Maastrichtian (Hell Creek) ecosystems. Their model suggested that the Maastrichtian ecosystem was more susceptible to a collapse in primary productivity, than was the Campanian ecosystem; that it would experience deeper collapse of secondary food chains at subsequent (higher) trophic levels.

Perhaps influenced by this work, Brusatte et al. (2014), saw the asteroid as the "fundamental cause" of the K-Pg extinction, but supposed that "longer term phenomena such as sea-level-mediated faunal restructuring and shorter term Deccan-induced climate changes may have made latest Maastrichtian communities less resilient to the impact, as 'press' events before the sudden and catastrophic 'pulse' of the impact" (p. 638). Yet, the Maastrichtian HCF ecosystem shows no evidence of having been "weakened" (e.g., pressed by external forces); it was simply in its construction and relationships potentially more susceptible to a collapse in primary production than was the Campanian one.

While Mitchell et al. (2012) note that "earlier ecological restructuring might have exacerbated the impact and severity of the end-Cretaceous extinction, at least in North America" (p. 18857), this no less points to an asteroid, than any other potential extinction agent, an observation recognized by Brusatte et al. (2014). Thus, we return here to the point that it is unclear how volcanism fits any of the data better than the asteroid as the agent of 
extinction. At best, multi-cause hypotheses, layer on redundant, equivocal causes onto an already satisfactory explanation.

\section{Conclusions}

To date, the HCF provides the finest record available of concurrent latest Cretaceous terrestrial paleoenvironments, biotas, and events. It thus remains the single most cited - and most important - indicator of what took place at the K-Pg boundary in the terrestrial realm. Regardless, all workers, whatever their opinions about what took place $66.043 \mathrm{Ma}$, have noted that in a global sense, the HCF formation represents a single data point, and that perhaps the single most important contribution that could be made would be to investigate with equivalent diligence another locality showing the same concurrence of $\mathrm{K}-\mathrm{Pg}$ indicators (see, for example, the discussion in Le Loeuff, 2012 and Brusatte et al., 2014, and references therein). To date, however, such localities have not yet been either discovered or recognized.

That said, has the HCF itself played out in terms of K-Pg events? We suspect not. Heretofore, a main focus of paleontological research has been the description of the plant and animal communities leading up to the K-Pg boundary, with an emphasis on the characterization of the K-Pg boundary by its casualties. As noted in the preceding text, the bane of all of this work has been stratigraphic control, and efforts should be redoubled in the HCF to bolster the stratigraphic precision. Perhaps the most promising way that this might be carried out would be through the use of numerical dating to, at a minimum, begin to provide numerical dates for the already extensive paleomagnetic studies that have been carried out in the formation. In this sense, the older study by Swisher et al. (1993) and the more recent one by Sprain et al. (2015) look forward to a potentially important research future for the HCF. That said, Sprain et al. (2015) used tonsteins preserved in Fort Union coals, an idea that goes back as far as an unsuccessful, cruder attempt reported in Fastovsky (1986). As the extinction 
dynamics are contained within the $\mathrm{HCF}$, new and creative approaches need to be initiated in that part of the $\mathrm{K}-\mathrm{Pg}$ section.

The HCF remains an important model system for asking some very important questions about stratigraphic resolution. Throughout many of the years of very intensive study, the questions asked have been ahead of the methods of resolution required to answer them. But, as we look at the long research trajectory in this area, we are sanguine, because for all the bumps and disagreements, the methods used continue to improve in refinement, and the resolution now is better than it ever has been.

Yet, the Hell Creek is a siliciclastic fluvial system; everything that is there was deposited, and there is a point at which fine details in a stratigraphic sequence are below the geological resolution of the unit; that is, its ability to precisely resolve sequential events. That level of resolution of course will vary depending upon the facies (and its depositional origin), and in some cases it might be sub-cm-level; in others, we may have already transcended it.

The selectivity of the extinction has provoked considerable discussion, from Archibald and Bryant (1990), to Sheehan and Fastovsky (1992), Archibald (1996), to Robertson et al. (2004). Yet, we feel, the subject is not fully explored. Thanks to Archibald and Bryant, 1990, we have a sense of the outlines of the pattern, but like so much about the extinction, the data can be interpreted in at least two mutually exclusive ways (e.g., Archibald, 1993; and Sheehan and Fastovsky, 1992; Fastovsky and Sheehan, 2005). Better, more mechanistically precise details about what actually occurs when a $10 \mathrm{~km}$ asteroid hits Earth (e.g., Robertson et al., 2004; 2013a, b) may help focus the discussion on the interpretation of the patterns of selectivity (Robertson et al., 2013b).

Finally, another area awaiting activity is, of course, the $\mathrm{K}-\mathrm{Pg}$ recovery, as it is preserved in the Fort Union. To be sure, there are some problems - the most obvious of which is the major facies change at the boundary, and the fact that it represents energetic, flooded, 
and unstable paleoenvironments, which Hell Creek faunas and floras - survivors or no would have found uncongenial. This must account for much of the difficulty in obtaining good specimen databases for the lowermost parts of the Puercan NALMA. As we have stressed, the great strength of this section is the coincidence of the various K-Pg boundary indicators, both biotic and abiotic; these need to be integrated thoughtfully to obtain the highest fidelity image of the early years of the Paleocene in the Western Interior of the Upper Great Plains.

\section{Acknowledgments}

David E. Fastovsky gratefully acknowledges the support of the Austrian-American Education Commission (through a Fulbright Scholarship), the Department für Lithosphärenforschung at the University of Vienna (Austria), and the Department of Geosciences, University of Rhode Island (USA). Antoine Bercovici is currently supported by a Deep Time Peter Buck Postdoctoral Fellowship from the NMNH Smithsonian Institution. We are thankful to Dean A. Pearson (Pioneer Trails Regional Museum, Bowman, ND), and to Tyler R. Lyson (Marmarth Research Foundation), for logistical support and assistance in the field. We are particularly grateful to the conveners of the September, 2014 Tremp (Spain) conference for both that event and for giving us the opportunity to contribute to this volume. Finally, our manuscript was aided significantly by the thoughtful, detailed reviews of Eric Buffetaut and Stephen Brusatte. 


\section{References Cited}

Alvarez, L.W., 1983. Experimental evidence that an asteroid impact led to the extinction of many species 65 million years ago. Proceedings of the National Academy of Sciences, 80, 627-642.

Alvarez, L.W., Alvarez, W., Asaro, F., Michel, H.V., 1980. Extraterrestrial cause for the Cretaceous-Tertiary extinction. Science 208, 1095-1108, doi:10.1126/science208.4448.1095.

Alvarez, W., Alvarez, L.W., Asaro, F., Michel, H.V., 1982. Current status of the impact theory for the terminal Cretaceous extinction. In: Silver, L.T., Schultz, P.H., (Eds.), Geological implications of impacts of large asteroids and comets on the Earth. Geological Society of America Special Paper 190, 305-315.

Alvarez, W., Kauffman, E.G., Surlyk, F., Alvarez, L.W., Asaro, F., Michel, H.V., 1984. Impact theory of mass extinctions and the invertebrate fossil record. Science 223, $1135-1141$.

Archibald, J.D., 1982. A study of Mammalia and geology across the Cretaceous-Tertiary boundary in Garfield County, Montana. University of California Publications in Geological Sciences 122, 286 p.

Archibald,, J.D., 1991. Letter to the Editor: American Scientist 78, 490-491.

Archibald, J.D., 1993. Major extinctions of land-dwelling vertebrates at the CretaceousTertiary boundary, eastern Montana: Comment and Reply. Geology 25, 91-92.

Archibald, J.D., 1996. Dinosaur extinction and the end of an era. What the fossils say. New York, Columbia University Press, 237 p.

Archibald, J.D., 2011. Extinction and Radiation: How the Fall of Dinosaurs Led to the Rise of Mammals. Johns Hopkins University Press, Baltimore, MD, 120 p. 
Archibald, J.D., Bryant, L.J., 1990. Differential Cretaceous/Tertiary extinctions of nonmarine vertebrates: Evidence from northeastern Montana. In: Sharpton, V.L., Ward, P.D. (Eds.), Global Catastrophes in Earth History: An Interdisciplinary Conference on Impacts, Volcanism, and Mass Mortality. Geological Society of America Special Paper 247, 549-562.

Archibald, J.D., and Fastovsky, D.E., 2004. Dinosaur extinction. In: Weishampel, D.B., Dodson, P.D., Osmólska, H., (Eds.), The Dinosauria (second edition). Berkeley, University of California Press, 672-684.

Archibald, J.D., Butler, R.F., Lindsay, E.H., Clemens, W.A., Dingus, L., 1982. Upper Cretaceous-Paleogene biostratigraphy and magnetostratigraphy, Hell Creek \& Tullock Formations, northeastern Montana. Geology 10, 153-159. doi:10.1130/0091-7613(1982)10<153:UCBAMH>2.0.CO;2.

Archibald, J.D., Clemens, W.A., Padian, K., Rowe, T., Macleod, N., Barrett, P.M., Gale, A., Holroyd, P., Sues, H.-D., Arens, N.C., Horner, J.R., Wilson, G.P., Goodwin, M.B., Brochu, C.A., Lofgren, D.L., Hurlbert, S.H., Hartman, J.H., Eberth, D.A., Wignall, P.B., Currie, P.J., Weil, A., Prasad, G.V.R., Dingus, L., Courtillot, V., Milner, A., Milner, A., Bajpai, S., Ward, D.J., and Sahni, A., 2010. Cretaceous extinctions: Multiple causes. Science 328, p. 973.

Arens, N.C., West, I.D., 2008. Press-pulse: a general theory of mass extinction? Paleobiology $34,456-471$.

Arens, N.C., Jahren, A.H., 2000. Carbon isotope excursion in atmospheric CO2 at the Cretaceous-Tertiary boundary: evidence from terrestrial sediments. Palaios 15, 314322.

Arens, N.C., Jahren, A.H., 2002. Chemostratigraphic correlation of four fossil-bearing sections in southwestern North Dakota. In: Hartman, J.H., Johnson, K.R., Nichols, 
D.J.; (Eds.), The Hell Creek Formation and the Cretaceous-Tertiary Boundary in the Northern Great Plains: An Integrated Continental Record of the End of the Cretaceous. Geological Society of America Special Paper 361, 75-93.

Arens, N.C., Jahren, A.H., Kendrick, D.C., 2014. Carbon isotope stratigraphy and correlation of plant megafossil localities in the Hell Creek Formation of eastern Montana, USA. In: Wilson, G.P., Clemens, W.A. Jr., Horner, J.R., Harman, J.H. (Eds.), Through the End of the Cretaceous in the Type Locality of the Hell Creek Formation in Montana and adjacent areas. Geological Society of America Special Paper 503, 149-171. doi10.1130/2014.2503(05).

Bamforth, E.L., Button, C.L., Larsson, H.C.E., 2014. Paleoclimate estimates and fire ecology immediately prior to the end-Cretaceous mass extinction in the Frenchman Formation (66 Ma), Saskatchewan, Canada. Palaeogeography, Palaeoclimatology, Palaeoecology 401, 96-110.

Barclay, R.S., Johnson, K.R., 2004. West Bijou site Cretaceous-Tertiary boundary, Denver Basin, Colorado. Geological Society of America Field Guide 5, 59-68.

Barclay, R.S., Johnson, K.R., Betterton, W.J., Dilcher, D.L., 2003. Stratigraphy and megaflora of a K-T boundary section in the eastern Denver Basin, Colorado. Rocky Mountain Geology 38, 45-71.

Barrera, E., Savin, S.M., 1999. Evolution of late Campanian-Maastrichtian marine climates and oceans. In: Barrera, E., and Johnson, C.C., (Eds.), Evolution of the CretaceousOcean Climate System. Geological Society of America Special Paper 332, 245-282.

Belt, E.S., Flores, R.M., Warwick, P.D., Conway, K.M., Johnson, K.R., Waskowitz, R.S., 1984. Relationship of fluviodeltaic facies to coal deposition in the lower Fort Union Formation (Paleocene), southwestern North Dakota. In; Rahmani, R.A., Flores, 
R.M., (Eds.), Sedimentology of Coal and Coal-Bearing Sequences: International Association of Sedimentologists Special Publication 7, 177-195.

Belt, E.S., Hicks, J.F., Murphy, D.A., 1997. A pre-Lancian regional unconformity and its relationship to Hell Creek paleogeography in southeastern Montana: University of Wyoming Contributions to Geology 31, 1-26.

Bercovici, A., Wood, J., Pearson, D.A., 2008. Detailed paleontologic and taphonomic techniques to reconstruct an earliest Paleocene fossil flora: an example from southwestern North Dakota, USA. Review of Palaeobotany and Palynology 151, $136-146$.

Bercovici, A., Pearson, D., Nichols, D.J., Wood, J., 2009. Biostratigraphy of selected K/T boundary sections in southwestern North Dakota, USA: toward a refinement of palynological identification criteria. Cretaceous Research 30, 632-658.

Bercovici, A., Vajda, V., Sweet, A., 2012a. Pollen and spore stratigraphy of the CretaceousPaleogene mass-extinction interval in the Northern Hemisphere. Journal of Stratigraphy $36,165-178$.

Bercovici, A., Vajda, V., Pearson, D., Villanueva-Amadoz, U., Kline, D., 2012b. Palynostratigraphy of John's Nose, a new Cretaceous-Paleogene boundary section in southwestern North Dakota, USA. Palynology 36, 36-47.

Blonder, B., Royer, D.L., Johnson, K.R., Miller, I., Enquist, B.J., 2014. Plant ecological strategies shift across the Cretaceous-Paleogene boundary. PLoS Biology 12, e1001949. doi:10.1371/journal.pbio.1001949.

Bohor, B.F., Izett, G., 1986. World-wide size distribution of shocked quartz at the K/T boundary: evidence for a North American impact site. Lunar and Planetary Sciences 52, 68-69. 
Bohor, B.F., Foord, E.E., Modreski, P.J., Triplehorn D.M., 1984. Mineralogic evidence for an impact event at the Cretaceous-Tertiary boundary. Science 224, 867-869. doi: 10.1126/science.224.4651.867.

Bohor, B.F., Modreski, P.J., Foord, E.E., 1987a. Shocked quartz in the Cretaceous-Tertiary boundary clays - evidence for a global disruption. Science 236, 705-709.

Bohor, B.F., Triplehorn, D.M., Nichols, D.J., Millard, H.T., 1987b. Dinosaurs, spherules and the "magic layer"; a new K-T boundary clay site in Wyoming. Geology 15, 896-899.

Braman, D.R., Sweet, A.R., 2012. Biostratigraphically useful Late Cretaceous-Paleocene Terrestrial palynomorphs from the Canadian Western Interior Sedimentary Basin, Palynology 36, 8-35.

Brinkhuis, H., Schiøler, P., 1996. Palynology of the Geulhemmerberg, Cretaceous/Tertiary boundary section (Limburg, SE Netherlands). Geologie en Mijnbouw 75, 193-213.

Brinkhuis, H., Bujak, J.P., Smit, J., Versteegh, G.J.M., Visscher, H., 1998. Dinoflagellatebased sea surface temperature reconstructions across the Cretaceous-Tertiary boundary. Palaeogeography, Palaeoclimatology, Palaeoecology 141, 67-83.

Brinkman, D.B., Newbrey, M.G., and Neuman, A.G., 2014. Diversity and paleoecology of actinopterygian fish from vertebrate microfossil localities of the Maastrichtian Hell Creek Formation of Montana. In: Wilson, G.P., Clemens, W.A., Horner, J.R., Harman, J.H., (Eds.), Through the End of the Cretaceous in the Type Locality of the Hell Creek Formation in Montana and adjacent areas. Geological Society of America Special Paper 503, 247-270.

Brown, B., 1907. The Hell Creek beds of the Upper Cretaceous of Montana: their relation to contiguous deposits, with faunal and floral lists and a discussion of their correlation: American Museum of Natural History Bulletin 24, 823-845. 
Brown, R.W., 1952. Tertiary strata in eastern Montana and western North and South Dakota: Billings Geological Society Guidebook 3, 89-92.

Brown, S.A.E., Scott, A.C., Glasspool, I.J., Collinson, M.E., 2012. Cretaceous wildfires and their impact on the Earth system. Cretaceous Research 36, 162-190.

Brusatte, S.L., Butler, R.J., Prieto-Márquez, Norell, M.A., 2012. Dinosaur morphological diversity and the end-Cretaceous extinction. Nature Communications 3:804 doi: $10.1038 /$ ncomms 1815 .

Brusatte, S.L., Butler, R.J., Barrett, P.M., Carrano, M.T., Evans D.C., Lloyd, G.T., Manion, P.D., Norell, M.A., Peppe, D.J., Upchurch, P., and Williamson, T.E., 2014. The extinction of the dinosaurs. Biological Reviews 90, 628-642, doi: 10.1111/brv.12128.

Bryant, L.J., 1989. Non-dinosaurian lower vertebrates across the Cretaceous-Tertiary boundary in northeastern Montana. University of California Pubications in the Geological Sciences 134, 107 p.

Buffetaut, E., 1987. Why the Maastrichtian regression did not cause terminal Cretaceous mass extinctions. Mémoires de la Société Géologique de France 150, 75-80.

Butler, R.D., 1980. Stratigraphy, sedimentology, and depositional environments of the Hell Creek Formation (late Cretaceous) and adjacent strata, Glendive area, Montana [unpubl. Ph.D. dissert.]. University of North Dakota at Grand Forks, 398 p.

Carvalho, M.R., Wilf, P., Barrios, H., Windsor, D.M., Currano, E.D., Labandeira, C.C., Jaramillo, C.A.,2014. Insect leaf-chewing damage tracks herbivore richness in modern and ancient forests. PLoS ONE 9, e94950.

doi:10.1371/journal.pone.0094950. 
Cascales-Miñana, B., Cleal, C.J., 2012. Plant fossil record and survival analyses. Lethaia 45, $71-82$.

Cascalas-Miñana, B., Cleal, C.J., 2014. The plant fossil record reflects just two great extinction events. Terra Nova 26, 195-200.

Chenet, A.-L., Courtillot, V., Fluteau, F., Gerard, M., Quidelleur, X, Khadri, S, Sabbaro, K., Thordarson, T., 2009. Determination of rapid Deccan eruptions across the Cretaceous-Tertiary boundary using paleomagnetic secular variation: constraints from analysis of eight new sections and synthesis for a 3500-m-thick composite section: Journal of Geophysical Research 114, B06103, doi10.1029/2008JB005644.

Cherven, V.B., Jacob, A.F., 1985. Evolution of Paleogene depositional systems, Williston Basin, in response to global sea level changes. In: Flores, R.M., Kaplan, S.S., (Eds.), Cenozoic Paleogeography of the West Central United States: Rocky Mountain Symposium No. 3, Rocky Mountain Section, Society of Economic Paleontologists and Mineralogists, Denver, 127-170.

Chin, K., Pearson, D.A., Ekdale, A.A., 2013. Fossil worm burrows reveal very early terrestrial animal activity and shed light on trophic resources after the end- Cretaceous mass extinction. PLoS ONE 8 (8), 8 e70920 http://dx.doi.org/10.1371/journal.pone.0070920.

Claeys, P., Kiessling, W., Alvarez, W., 2002. Distribution of Chicxulub ejecta at the Cretaceous-Tertiary boundary. In: Koeberl, C., MacLeos, K.G., (Eds.), Catastrophic events and mass extinctions: impacts and beyond. Geological Society of America Special Paper 356, 55-68.

Clarke, J., Tambussi, C.P., Noriega, J.I., Erickson, J.M., Ketcham, R.A. 2005. Definitive fossil evidence for the extant radiation of Aves in the Cretaceous. Nature 433, 305308. 
Cleal, C.J., Uhl, D., Cascales-Miñana, B., Thomas, B.A., Bashforth, A.R., King, S.C., Zodrow, E.L., 2012. Plant biodiversity changes in Carboniferous tropical wetlands. Earth-Science Reviews 114, 124-155.

Clemens, W.A., 2002. Evolution of the mammalian fauna across the Cretaceous-Tertiary boundary in northeastern Montana and other areas of the Western Interior. In: Hartman, J., Johnson, K.R., Nichols, D.J., (Eds.), The Hell Creek Formation and the Cretaceous-Tertiary Boundary in the northern Great Plains. Geological Society of America Special Paper 361, 217-245.

Clemens, W.A., and Archibald, J.D., 1980. Evolution of terrestrial faunas during the Cretaceous-Tertiary transition. In: Ecosystèmes Continentaux du Mésozoïque. Société Géologique de France, Mémoire 139 (new series), 67-74.

Clemens, W.A., Jr., Hartman, J.H., 2014. From Tyrannosaurus rex to asteroid impact: early studies (1901 - 1980) of the Hell Creek Formation in its type area. In; Wilson, G.P., Clemens, W.A., Horner, J.R., Harman, J.H., (Eds.), Through the End of the Cretaceous in the Type Locality of the Hell Creek Formation in Montana and adjacent areas. Geological Society of America Special Paper 503, 1-87. doi10.1130/2014.2503(01).

Clemens, W.A., Archibald, J.D., Hickey, L.J 1981. Out with a whimper, not a bang. Paleobiology 7, 293-298.

Collier, A.J., Knechtel, M.M., 1939. The Coal Resources of McCone County, Montana. U.S. Geological Survey Bulletin 905, 80 p.

Cook, T.D., Newbrey, M.G., Brinkman, D.B., Kirkland, J.I., 2014. Euselachians from freshwater deposits of the Hell Creek Formation of Montana. In: Wilson, G.P., Clemens, W.A., Horner, J.R., Harman, J.H., (Eds.), Through the End of the Cretaceous in the Type Locality of the Hell Creek Formation in Montana and 
adjacent areas. Geological Society of America Special Paper 503, 229-246, doi10.1130/2014.2503(08).

Courtillot, V., 1995. La vie en catastrophes : Du hasard dans l'évolution des espèce. Fayard, Paris, $278 \mathrm{p}$.

Cracraft, J. Clarke, J. 2001. The basal clades of modern birds. In: Gauthier, J. Gall, L. F., (Eds.), New perspectives on the origin and early evolution of birds. Proceedings of the International Symposium in Honor of John H. Ostrom.

Cvancara, A.M., and Hoganson, J.W., 1993. Vertebrates of the Cannonball Formation (Paleocene) in North and South Dakota. Journal of Vertebrate Paleontology 13, 1-23.

DePalma, R., Cichocki, F., Dierick, M., Feeney, R., 2015. Preliminary notes on the first recorded amber insects from the Hell Creek Formation. The Journal of Paleontological Sciences C.10.0001, 7p.

Dingus, L.W., 1984. Effects of stratigraphic completeness on interpretations of extinction rates across the Cretaceous-Tertiary boundary. Paleobiology 10, 420-438.

Dingus, L., Norell, M.A., 2010. Barnum Brown. The man who discovered Tyrannosaurus rex. University of California Press, 368 p.

Dodson, P., 1996. The Horned Dinosaurs. Princeton, New Jersey, Princeton University Press, $346 \mathrm{p}$.

Donovan, M.P., Wilf, P., Labandeira, C.C., Johnson, K.R., Peppe, D.J., 2014. Novel insect leaf-mining after the end-Cretaceous extinction and the demise of Cretaceous leaf miners, Great Plains, USA. PLoS ONE 9, e103542. doi:10.1371/journal.pone.0103542.

Erwin, D.H., 2006. Extinction. Princeton University Press, Princeton, NJ, 296 p. 
Estes, R., Berberian, P., Meszoely, C., 1969. Lower vertebrates from the Late Cretaceous Hell Creek Formation, McCone County, Montana. Brevoria 337, 1-33.

Fastovsky, D. E., 1986. Paleoenvironments of vertebrate-bearing strata at the CretaceousPaleogene boundary in northeastern Montana and southwestern North Dakota [unpub. Ph.D. dissert.]. University of Wisconsin-Madison, $301 \mathrm{p}$.

Fastovsky, D.E., 1987. Paleoenvironments of vertebrate-bearing strata during the CretaceousPaleogene transition in eastern Montana and western North Dakota: Palaios 2, 282 295.

Fastovsky, D. E., Dott, R. H., Jr., 1986. Sedimentology, stratigraphy, and extinctions during the Cretaceous-Paleogene transition at Bug Creek, Montana. Geology 14, 279-282.

Fastovsky, D.E., McSweeney, K., 1987. Paleosols spanning the Cretaceous-Paleogene transition, eastern Montana and western North Dakota: Geol. Soc. Am. Bull. 99, 6677.

Fastovsky, D.E., Sheehan, P.M., 2005. The extinction of the dinosaurs in North America: GSA Today 15, 4-10. doi: 10:1130/1052-5173

Fastovsky, D.E., McSweeney, K., Norton, D.L., 1989. Evidence for pedogenic alteration of the Cretaceous-Paleogene boundary clay layer, eastern Montana: Journal of Sedimentary Petrology 59, 758-767.

Fastovsky, D.E., Sheehan, P.M., Isbell, J., Grandpre, R., 2008. Anomalous, temporary terrestrial sedimentary environments following Cretaceous-Tertiary ecosystem disruptions: North America, Asia, and Europe: Geological Society of America Abstracts with Programs 40, p. 324.

Fleming, R.F., Nichols, D.J., 1988. The "Tschudy effect": fern-spore abundance anomaly at the Cretaceous-Tertiary boundary. Palynology 12, 238. 
Fleming, R.F., Nichols, D.J., 1990. The fern-spore abundance anomaly at the CretaceousTertiary Boundary: a regional bio-event in western North America. In: Kauffman, E.G., Walliser, O.H., (Eds.), Extinction Events in Earth History. Lectures Notes in Earth Sciences, Springer Verlag, New York 30, 351-364.

Florsheim, J.L., Mount, J.F., 2003, Changes in lowland floodplain sedimentation processes: pre-disturbance to pos-rehabilitation, Consumes River, CA. Geomorphology 56, $305-323$.

Friis, E.M., Crane, P.R., Pedersen, K.R., 2011. Early Flowers and Angiosperm Evolution. Cambridge University Press, Cambridge.

Frye, C.I., 1969. Stratigraphy of the Hell Creek Formation in North Dakota: North Dakota Geological Survey Bulletin 54, 65 p.

Glen, W., 1994. The Mass-Extinction Debates: How Science Works in a Crisis. Stanford University Press, Menlo Park, CA, 370 p.

Grandpre, R., Fastovsky, D.E., Sheehan, P.M., 2008. What if the effects of a mass extinction are so pervasive that they can be recognized in the depositional environments? Journal of Vertebrate Paleontology 28 (Supplement).

Grandpre, R., Schauer, A., Samek, K., Veeger, A.I., Ward, P., Fastovsky, D.E., 2013. Testing the terrestrial d13C Cretaceous-Paleogene (K-Pg) chemostratigraphic marker. Palaeogeography, Palaeoclimatology, Palaeoecology 381, 67-75. http://dx.doi.org/10.1016/j.palaeo.2013.04.015

Hartman, J., Johnson, K.R., Nichols, D.J., 2002. The Hell Creek Formation and the Cretaceous-Tertiary Boundary in the northern Great Plains: Geological Society of America Special Paper 361, 520 p. 
Herngreen, G.F.W., Chlonova, A.F., 1981. Cretaceous microfloral provinces. Pollen et Spores $23,441-555$.

Herngreen, G.F.W., Kedves, M., Rovnina, L.V., Smirnova, S. B., 1996. Cretaceous palynofloral provinces: a review. In: Palynology: Principles and Applications, Volume 3. In: J. Jansonius, J., D.C. McGregor, D.C., (Eds.), American Association of Stratigraphic Palynologists Foundation, Salt Lake City, 1157-88.

Hesselbo, S.P., Robinson, S.A., Surlyk, F., Piasecki, S., 2002, Terrestrial and marine extinction at the Triassic-Jurassic boundary synchronized with major carbon-cycle perturbation: A link to initiation of massive volcanism? Geology 30, 251-254.

Hickey, L.J., 1981. Land plant evidence compatible with gradual, not catastrophic, change at the end of the Cretaceous. Nature 292, 529-531.

Hicks, J.F., Johnson, K.R., Obradovich, J.D., Tauxe, L., Clark, D., 2002. Magnetostratigraphy and geochronology of the Hell Creek and basal Fort Union formations of southwestern North Dakota and a recalibration of the age of the Cretaceous-Tertiary boundary. In: Hartman, J., Johnson, K.R., Nichols, D.J., (Eds.), The Hell Creek Formation and the Cretaceous-Tertiary Boundary in the northern Great Plains. Geological Society of America Special Paper 361, 35-55.

Hoganson, J.W., Murphy, E.C., 2002. Marine Brien Member (Maastrichtian) of the Hell Creek Formation in North Dakota: stratigraphy, vertebrate fossil record, and age. In: Hartman, J., Johnson, K.R., Nichols, D.J., (Eds.), The Hell Creek Formation and the Cretaceous-Tertiary Boundary in the northern Great Plains: Geological Society of America Special Paper 361 247-269.

Holryod, P.A., Hutchinson, J.H., 2002. Patterns of geographic variation in latest Cretaceous vertebrates: evidence from the turtle component. In: Hartman, J., Johnson, K.R., Nichols, D.J., (Eds.), The Hell Creek Formation and the Cretaceous-Tertiary 
Boundary in the northern Great Plains. Geological Society of America Special Paper 361, 177-190.

Holroyd, P.A., Wilson, G.P., Hutchinson, J.H., 2014. Temporal changes within the latest Cretaceous and early Paleogene turtle faunas of northeastern Montana. In; Wilson, G.P., Clemens, W.A. Jr., Horner, J.R., Harman, J.H., (Eds.), Through the End of the Cretaceous in the Type Locality of the Hell Creek Formation in Montana and adjacent areas. Geological Society of America Special Paper 503, 299-312. doi:10.1130/2014.2503(11).

Hotton, C.L., 1988. Palynology of the Cretaceous-Tertiary boundary in central Montana, U.S.A., and its implication for extraterrestrial impact. Ph.D. dissertation, University of California, Davis, California.

Hotton, C.L., 2002. Palynology of the Cretaceous-Tertiary boundary in central Montana: Evidence for extraterrestrial impact as a cause for the terminal Cretaceous extinction. In: Hartman, J.H., Johnson, K.R., Nichols, D.J. (Eds.), The Hell Creek Formation and the Cretaceous-Tertiary boundary in the Northern Great Plains: an Integrated Continental Record of the End of the Cretaceous. Geological Society of America Special Paper 361, 191-216.

Hunter, J.P., 1999. The radiation of Paleocene mammals with the demise of the dinosaurs: Evidence from southwestern North Dakota. North Dakota Academy of Science Proceedings 53, 141-144.

Hunter, J.P., Archibald, J.D., 2002. Mammals from the end of the age of dinosaurs in North Dakota and southwestern Montana, with a reappraisal on geographic differentiation among Lancian mammals. In: Hartman, J.H., Johnson, K.R., Nichols, D.J. (Eds.), The Hell Creek Formation and the CretaceousTertiary boundary in the Northern Great Plains: an Integrated Continental Record of the End of the Cretaceous. Geological Society of America Special Paper 361, 473-501. 
Hurlbert, S.H., Archibald, J.D., 1995. No statistical support for sudden (or gradual) extinction of dinosaurs. Geology 23, 881-884.

Hutchison, J.H., Archibald, J.D., 1989. Diversity of turtles across the Cretaceous/Tertiary boundary in northeastern Montana. Palaeogeography, Palaeoclimatology, Palaeoecology, 55, 1-22.

Izett, G.A., 1990. The Cretaceous/Tertiary boundary interval, Raton Basin, Colorado and New Mexico, and its content of shock-metamorphosed minerals: evidence relevant to the K-T boundary impact-extinction theory. Geological Society of America Special Paper 249.

Jerzykiewicz, T., Sweet, A.R., 1986. The Cretaceous-Tertiary boundary in the central Alberta Foothills: stratigraphy. Canadian Journal of Earth Sciences 23, 1356-1374.

Johnson, K.R., 1989. A high-resolution megafloral biostratigraphy spanning the CretaceousTertiary in the northern Great Plains (unpubl. Ph.D. thesis), Yale University, New Haven, CT 556 p.

Johnson, K.R., 1992. Leaf-fossil evidence for extensive floral extinction at the CretaceousTertiary boundary, North Dakota, USA. Cretaceous Research 13, 91-117. doi: 10.1016/0195-6671(92)90029-P.

Johnson, K.R., 2002. Megafloral of the Hell Creek and lower fort Union Formations in the western Dakotas: vegetational response to climate change, the Cretaceous-Tertiary boundary event, and rapid marine transgression. In: Hartman, J., Johnson, K.R., Nichols, D.J., (Eds.), The Hell Creek Formation and the Cretaceous-Tertiary Boundary in the northern Great Plains: Geological Society of America Special Paper 361, 329-391. 
Johnson, K.R., Hickey, L.J., 1990. Megafloral change across the Cretaceous/Tertiary boundary in the northern Great Plains and Rocky Mountains, USA. In: Shapton, V.L., Ward, P.D. (Eds.), Global catastrophes in earth history: an interdisciplinary conference on impacts, volcanism, and mass mortality. Geological Society of America Special Paper 247, 433-444.

Johnson, K.R., Nichols, D.J., Attrep, M. Jr, Orth, C.J., 1989. High-resolution leaf-fossil record spanning the Cretaceous/Tertiary boundary. Nature 307, 224-228.

Johnson, K.R., Nichols, D.J., Hartman, H.H., 2002. Hell Creek Formation: a 2002 synthesis. In; Hartman, J., Johnson, K.R., Nichols, D.J., (Eds.), The Hell Creek Formation and the Cretaceous-Tertiary Boundary in the northern Great Plains: Geological Society of America Special Paper 361, 503-510.

Keller, G., Lindinger, M., 1989. Stable isotope, TOC, and CaCO3 record across the Cretaceous/Tertiary boundary at El Kef, Tunisia. Palaeogeography, Palaeoclimatology, Palaeoecology 73, 243-266.

Kroeger, T. J., 2002. Palynology of the Hell Creek Formation (Upper Cretaceous, Maastrichtian) in northwestern South Dakota : Effects of paleoenvironment on the composition of palynomorph assemblages. In: Hartman, J.H., Johnson, K.R., Nichols, D.J. (Eds.), The Hell Creek Formation and the Cretaceous-Tertiary boundary in the Northern Great Plains: an Integrated Continental Record of the End of the Cretaceous. Geological Society of America Special Paper 361, 457-472.

Labandeira, C.C., Currano, E.D., 2013. The fossil record of Plant-Insect dynamics. Annual Review of Earth and Planetary Science 41, 287-311.

Labandeira, C.C., Johnson, K.R. Lang, P. 2002a. Preliminary assessment of insect herbivory across the Cretaceous-Tertiary boundary: Major extinction and minimum rebound. In: Hartman, J.H., Johnson, K.R., Nichols, D.J. (Eds.), The Hell Creek Formation 
and the Cretaceous-Tertiary boundary in the Northern Great Plains: an Integrated Continental Record of the End of the Cretaceous. Geological Society of America Special Paper 361, 297-318.

Labandeira, C.C., Johnson, K.R., Wilf, P., 2002b. Impact of the terminal Cretaceous event on plant-insect associations. Proceedings of the National Academy of Sciences 99, 2061-2166.

Laird, W.M., and Mitchell, R.H., 1942. The geology of the southern part of Morton County, North Dakota. North Dakota Geological Survey Bulletin 14, 42 p.

LeCain, R., Clyde, W.C., Wilson, G.P., Riedel, J., 2014. Magnetostratigraphy of the Hell Creek and lower Fort Union Formations in northeastern Montana. In; Wilson, G.P., Clemens, W.A. Jr., Horner, J.R., Harman, J.H., (Eds.), Through the End of the Cretaceous in the Type Locality of the Hell Creek Formation in Montana and adjacent areas. Geological Society of America Special Paper 503, 137-147. doi:10.1130/2014.2503(04).

Le Loeuff, J. 2012. Paleobiogeography and biodiversity of Late Maastrichtian dinosaurs: how many dinosaur species went extinct at the Cretaceous-Tertiary boundary? Bulletin de la Société géologique de France, 183, no 6, pp. 547-559.

Leffingwell, H.A., 1970. Palynology of Lance (Late Cretaceous) and Fort Union (Paleocene) Formations of the type Lance area, Wyoming, in Kosanke, R.M., and Cross, A.T., (Eds.), Symposium on Palynology of the Late Cretaceous and Early Tertiary. Geological Society of America Special Paper 127, 1-64.

Lerbekmo, J.F., Sweet, A.R., St. Louis, R.M., 1987. The relationship between the iridium anomaly and palynological floral events at three Cretaceous-Tertiary boundary localities in western Canada. Geological Society of America Bulletin 99, 325-330. 
Longrich, N.R., Tokaryk, T., Field, D.J., 2011. Mass extinction of birds at the CretaceousPaleogene (K-Pg) boundary. Proceedings of the National Academy of Sciences 108, $1523-1527$.

Longrich, N.R., Bhullar, B.-A.S., Gauthier, J.A., 2013. Mass extinction of lizards and snakes at the Cretaceous-Paleogene boundary. Proceedings of the National Academy of Sciences 109, 21396-21401. doi/10.1073/pnas.1211526110.

Lund, S.P., Hartman, J.H., Banerjee, S.K., 2002. Magnetostratigraphy of interfingering upper Cretaceous-Paleocene marine and continental strata of the Williston Basin, North Dakota and Montana. In: Hartman, J., Johnson, K.R., Nichols, D.J., (Eds.), The Hell Creek Formation and the Cretaceous-Tertiary Boundary in the northern Great Plains. Geological Society of America Special Paper 361, 57-74.

Lyson, T.R., Joyce, W. G., 2009. A Revision of Plesiobaena (Testudines: Baenidae) and an Assessment of Baenid Ecology Across the K/T Boundary. Journal of Paleontology 83(6), 833-853. doi: http://dx.doi.org/10.1666/09-035.1

Lyson, T.R., Bercovici, A., Chester, S.G.B., Sargis, E.J., Pearson, D., Joyce, W.G., 2011a. Dinosaur extinction: closing the "3 m gap". Biology Letters 7, 925-928. doi:10.1098/rsbl.2011.0470.

Lyson, T.R., Joyce, W. G., Knauss, G. E., Pearson, D. A., 2011b. Boremys (Testudines, Baenidae) from the Latest Cretaceous and Early Paleocene of North Dakota: an 11million-year range extension and an additional K/T survivor. Journal of Vertebrate Paleontology 31(4), 729-737.

MacLeod, N., Rawson, P.F., Forey, P.L., Banner, F.T., BouDagher-Fadel, M.K., Bown, P.R., Burnett, J.A., Chambers, P., Culver, S., Evans, S.E., Jeffrey, C., Kaminski, M.A., Lord, A.R., Milner, A.C., Milner, A.R., Morris, N., Owen, E., Rosen, B.R., Smith, 
A.B., Taylor, P.D., Urquhardt, E., Young, J.R., 1997. The Cretaceous-Tertiary biotic transition. Geological Society of London Journal 154, 265-292.

Maruoka, T., Koeberl, C., Bohor, B.F., 2007. Carbon isotopic compositions of organic matter across continental Cretaceous-Tertiary $(\mathrm{K}-\mathrm{T})$ boundary sections; implications for paleoenvironment after the K-T impact event. Earth and Planetary Science Letters $253,226-238$.

McElwain, J.C. and Punyasena, S.W., 2007. Mass extinction events and the plant fossil record. Trends in Ecology and Evolution 22, 548-557.

Mitchell, J.S., Roopnarine, P.D., Angielczyk, K.D., 2012. Late Cretaceous restructuring of terrestrial communities facilitated the end-Cretaceous mass extinction in North America. Proceedings of the National Academy of Sciences 109, 18857-18861. doi/10.1073/pnas.1202196109.

Moore, W.L., 1976. The stratigraphy and environments of deposition of the Cretaceous Hell Creek Formation (reconnaissance) and the Paleocene Ludlow Formation (detailed), southwestern North Dakota. North Dakota Geological Survey Report of Investigations $56,40 \mathrm{p}$.

Moore, J.R., Wilson, G.P., Sharma, M., Hallock, H.R., Braman, D.R., Renne, P.R., 2014. Assessing the relationships of the Hell Creek-Fort Union contact, CretaceousPaleogene boundary, and Chicxulub impact ejecta horizon at the Hell Creek Formation lectotype, Montana, USA. In; Wilson, G.P., Clemens, W.A. Jr., Horner, J.R., Harman, J.H., (Eds.), Through the End of the Cretaceous in the Type Locality of the Hell Creek Formation in Montana and adjacent areas. Geological Society of America Special Paper 503, 123-135. doi10.1130/2104.2503(03). 
Murphy, E.C., Nichols, D.J., Hoganson, J.W., Forsman, N.F., 1995. The Cretaceous-Tertiary boundary in south-central North Dakota. North Dakota Geological Survey Report of Investigations $98,41 \mathrm{p}$.

Murphy, E.D., Hoganson, J.W., Johnson, K.R., 2002, Lithostratigraphy of the Hell Creek Formation. In: Hartman, J., Johnson, K.R., Nichols, D.J., (Eds.), The Hell Creek Formation and the Cretaceous-Tertiary Boundary in the northern Great Plains. Geological Society of America Special Paper 361, 9-34.

Nichols, D.J., 1990. Geologic and biostratigraphic framework of the non-marine CretaceousTertiary boundary interval in western North America. Review of Palaeobotany and Palynology 70, 77-88.

Nichols, D.J., 1994. A revised palynostratigraphic zonation of the nonmarine Upper Cretaceous, Rocky Mountain region, United States. In: Caputo, M.V., Peterson, J.A., Franczyk, K.J., (Eds.), Mesozoic systems of the Rocky Mountain Region, USA. Society of Economic Paleontologists and Mineralogists, Rocky Mountain Section.

Nichols, D.J., 2002. Palynology and palynostratigraphy of the Hell Creek Formation in North Dakota: A microfossil record of plants at the end of Cretaceous time: In: Hartman, J.H., Johnson, K.R., Nichols, D.J. (Eds.), The Hell Creek Formation and the Cretaceous-Tertiary boundary in the Northern Great Plains: an Integrated Continental Record of the End of the Cretaceous. Geological Society of America Special Paper 361, 393-456.

Nichols, D.J., 2003. Palynostratigraphic framework for age determination and correlation of the nonmarine lower Cenozoic of the Rocky Mountains and Great Plains region. In: Raynolds, R.G., Flores, R.M. (Eds). Cenozoic Systems of the Rocky Mountain Region. Denver, Colorado. Rocky Mountain Section of the Society for Sedimentary Geology (SEPM), 107-134. 
Nichols, D.J., 2007. Selected plant-microfossil records of the terminal Cretaceous event in terrestrial rocks, western North America. Palaeogeography, Palaeoclimatology, Palaeoecology 255, 22-34.

Nichols, D.J., Fleming, R.F., 1990. Plant microfossil record of the terminal Cretaceous event in the western United States and Canada. In: Shapton, V.L., Ward, P.B. (Eds.), Global catastrophes in earth history: an interdisciplinary conference on impacts, volcanism, and mass mortality. Geological Society of America Special Paper 247, pp. $445-455$.

Nichols, D.J., Johnson, K.R., 2002. Palynology and microstratigraphy of Cretaceous-tertiary boundary sections in southwester North Dakota. In: Hartman, J., Johnson, K.R., Nichols, D.J., (Eds.), The Hell Creek Formation and the Cretaceous-Tertiary Boundary in the northern Great Plains. Geological Society of America Special Paper $361,95-143$.

Nichols, D.J., Johnson, K.R., 2008. Plants and the K-T Boundary. Cambridge University Press, 280p.

Nichols, D.J., Jarzen, D.M., Orth, C.J., Oliver, P.Q., 1986. Palynological and iridium anomalies at Cretaceous-Tertiary boundary, south-central Saskatchewan. Science $231,714-717$.

Nichols, D.J., Brown, J.L., Attrep, M., Jr., Orth, C.J., 1992a. A new Cretaceous-Tertiary boundary locality in the western Powder River Basin, Wyoming: biological and geological implications. Cretaceous Research 13, 3-30.

Nichols, D.J., Hickey, L.J., McWeeney, L.J., Wolfe, J.A., 1992b. Plants and the K/T boundary; discussion and reply. Nature 356, 295-296. 
Nichols, D.J., Murphy, E.C., Johnson, K.R., Betterton, W.J., 2000. A second K-T boundary locality in North Dakota verified by palynostratigraphy and shocked quartz. Geological Society of America Abstracts with Programs 32(7), p. 130.

Nordt, L., Atchley, S., Dworkin, S., 2003. Terrestrial evidence for two greenhouse events in the latest Cretaceous, GSA Today 13, 4-9. doi:10.1130/10525173(2003)013<4TEFTGE>2.0CO;2.

Norton, N.J., Hall, J.W., 1969. Palynology of Upper Cretaceous and Lower Tertiary in the type locality of the Hell Creek Formation, Montana, U.S.A. Palaeontographica Arbeitlung B 125, 1-64.

Oltz, D.F., 1969. Numerical analyses of palynological data from Cretaceous and early Tertiary sediments in east central Montana. Palaeontographica Abteilung B, Palaophytologie 128, 90-166.

Orth, C.J., Gilmore, J.S., Knight, J.D., Pillmore, C.L., Tschudy, R.H., Fassett, J.E., 1981. An iridium anomaly at the Cretaceous-Tertiary boundary in northern New Mexico. Science 214, 1341-1343.

Orth, C.J., Gilmore, J.S., Knight, J.D., Pillmore, C.L., Tschudy, R.H., Fassett, J.E., 1982. Iridium abundance measurements across the Cretaceous/Tertiary boundary in the San Juan and Raton Basins of northern New Mexico. In: Silver, L.T., Schultz, P.H., (Eds.), Geological implications of impacts of large asteroids and comets on the Earth. Geological Society of America Special Paper 190, 423-433.

Pearson, D.A., Schaefer, T., Johnson, K.R., Nichols, D.J., 2001. Palynologically calibrated vertebrate record from North Dakota consistent with abrupt dinosaur extinction at the Cretaceous-Tertiary boundary. Geology 29, 39-42. 
Pearson, D.A., Schaefer, T., Johnson, K.R., Nichols, D.J., Hunter, J.P., 2002. Vertebrate biostratigraphy of the Hell Creek Formation in southwestern North Dakota and northwestern South Dakota. In: Hartman, J., Johnson, K.R., Nichols, D.J., (Eds.), The Hell Creek Formation and the Cretaceous-Tertiary Boundary in the northern Great Plains. Geological Society of America Special Paper 361, 145-167.

Peppe, D.J., 2010. Megafloral change in the early and middle Paleocene in the Williston Basin, North Dakota, USA. Palaeogeography, Palaeoclimatology, Palaeoecology 298, 224-234.

Peppe, D.J., Evans, D.A.D., Smirnov, A.V., 2009. Magnetostratigraphy of the Ludlow Member of the Fort Union Formation (Lower Paleocene) of the Williston Basin in North Dakota. Geological Society of America Bulletin 212, 65-79. doi:10.1130/B26353.1

Peterson, J.A., 1986. Paleotectonics and sedimentation in the Rocky Mountain region, United States. American Association of Petroleum Geologists Memoir 41, 693 p.

Pillmore, C.L., Tschudy, R.H., Orth, C.J., Gilmore, J.S., Knight, J.D., 1984. Geologic framework of nonmarine Cretaceous-Tertiary boundary sites, Raton Basin, New Mexico and Colorado. Science 223, 1180-1183.

Pollastro, R.M., Pillmore, C.L., 1987. Mineralogy and petrology of the Cretaceous-Tertiary boundary clay bed and adjacent clay-rich rocks, Raton Basin, New Mexico and Colorado. Journal of Sedimentary Petrology 57, 456-466.

Rehan, S.M., Leys, R., Schwarz, M.P., 2013. First evidence for a massive extinction event affecting bees close to the K-T boundary. PLoS ONE 8, e76683. doi:10.1371/journal.pone.0076683. 
Renne, P.R., Swischer, C.C., Deino, A.L., Karnewr, D.B., Owens, T.L., DePaolo, D.J., 1998. Intercalibration of standards, absolute ages and uncertainties in 40Ar-39Ar dating. Chemical Geology - Isotope Geoscience Section 145, 117-152.

Renne, P.R., Deino, A.L., Hilgen, F.J., Kuiper, K.F., Mark, D.F., Mitchell, W.S. III, Morgan, L.E., Mundil, R., Smit, J., 2013. Time Scales of Critical Events Around the Cretaceous-Paleogene Boundary. Science 339, 684-687.

Retallack, G.J., 1994. A pedotype approach to latest Cretaceous and earliest Tertiary paleosols in eastern Montana. Geological Society of America Bulletin 106, 1377-1397.

Retallack, G. J., Leahy, G. D., Spoon, M. D., 1987. Evidence from paleosols for ecosystem changes across the Cretaceous/Tertiary boundary in eastern Montana. Geology 15, $1090-1093$.

Robertson, D.S., McKenna, M.C., Toon, O.B., Hope, S., Lillegraven, J.A., 2004. Survival in the first hours of the Cenozoic. Geological Society of America Bulletin 116, 760 768. doi:10.1120/B25402.1.

Robertson, D.S., Lewis, W.M., Sheehan, P.M., Toon, O.B., 2013a. K-Pg extinction: Reevaluation of the heat-fire hypothesis. Journal of Geophysical Research biogeosciences 118, 1-8. doi:10.1002/jgrg.20018, 2013

Robertson, D.S., Lewis, W.M., Sheehan, P.M., Toon, O.B., 2013b. K-Pg extinction patterns in marine and freshwater environments: The impact winter model. Journal of Geophysical Research biogeosciences 118, 1-9. doi:10.1002/jgrg.20086, 2013.

Russell, D.A., 1982. A paleontological consensus on the extinction of the dinosaurs? In: Silver, L.T., Schultz, PH., (Eds.), Geological Implications of Large Asteroids and Comets on the Earth. Geological Society of America Special Paper 190, 401-405. 
Sahney, S., Benton, M.J. and Falcon-Lang, H.J., 2010. Rainforest collapse triggered Carboniferous tetrapod diversification in Euramerica. Geology 38, 1079-1082.

Saito, T., Yamanoi, T., Kaiho, K., 1986. End-Cretaceous devastation of terrestrial flora in the boreal Far East. Nature 323, 253-255.

Sarjeant, W.A.S., 1996. Dinosaur extinction: Sudden or slow, cataclysmic or climatic? Geoscience Canada 23, 161-164.

Saunders, A., Rechow, M., 2009. The Siberian Traps and the End-Permian mass extinction: a critical review. Chinese Science Bulletin 54, 20-37.

Schoene, B., Samperton, K.M., Eddy, M.P., Keller, G., Adatte, T., Bowring, S., Khadri, S.F.R., Gertsch, B., 2015. U-Pb geochronology of the Deccan Traps and relation to the end-Cretaceous mass extinction. Science 347, 182-184. doi:

10.1126/science.aaa0118.

Schulte, P., Alegret, L., Arenillas, I., Arz, J.A., Barton, P.J., Bown, P.R., Bralower, T.J., Christeson, G.L., Claeys, P., Cockell, C.S., Collins, G.S., Deutsch, A., Goldin, T.J., Goto, K., Grajales-Nishimura, J.M., Grieve, R.A.F., Gulick, S.P.S., Johnson, K.R., Kiessling, W., Koeberl, C., Kring, D.A., MacLeod, K.G., Matsui, T., Melosh, J., Montanari, A., Morgan, J.V., Neal, C.R., Nichols, D.J., Norris, R.D., Pierazzo, E., Ravizza, G., Rebolledo-Vieyra, M., Reimold, W.U., Robin, E., Salge, T., Speijer, R.P., Sweet, A.R., Urrutia-Fucugauchi, J., Vajda, V., Whalen, M.T., Willumsen, P.S., 2010. The Chicxulub asteroid impact and mass extinction at the CretaceousPaleogene boundary. Science 327, 1214-1218.

Self, S., Widdowson, M., Thordarson, T., Jay, A.E., 2006. Volatile fluxes during flood basalt eruptions and potential effects on the global environment: a Deccan perspective. Earth and Planetary Science Letters 248, 518-532. doi:10.1016/j.eps1.2006.05.041. 
Sheehan, P.M., Fastovsky, D.E., 1992. Major extinctions of land-dwelling vertebrates at the Cretaceous-Tertiary boundary, eastern Montana. Geology 20, 556-560.

Sheehan, P.M., Fastovsky, D.E., 1993. Major extinctions of land-dwelling vertebrates at the Cretaceous-Tertiary boundary, eastern Montana: Comment and Reply. Geology 25, $92-93$.

Sheehan, P.M., Fastovsky, D.E., Hoffmann, R.G., Berghaus, C.B., Gabriel, D.L., 1991. Sudden extinction of the dinosaurs. Latest Cretaceous, upper Great Plains, USA. Science 254, 835-839.

Sheehan, P.M., Fastovsky, D.E., Barreto, C., Hoffman, R.G., 2000. Dinosaur abundance was not declining in a "3 m gap" at the top of the Hell Creek Formation, Montana and North Dakota. Geology 28, 523-526. doi:10.1130/00917613(2000)28<523:DAWNDI>2.0.CO;2.

Signor, P.W., III, Lipps, J.H., 1982. Sampling bias, gradual extinction patterns, and catastrophes in the fossil record. In: Silver, L.T., Schultz, P.H., (Eds.), Geological implications of impacts of large asteroids and comets on Earth. Geological Society of America Special Paper 190, 291-296.

Sloan, R.E., Rigby, J.K., Jr., Van Valen, L., Gabriel, D., 1986. Gradual dinosaur extinction and simultaneous ungulate radiation in the Hell Creek Formation. Science 232, 629_ 633.

Smit, J., van der Kaars, W.A., 1984. Terminal Cretaceous extinctions in the Hell Creek area, Montana: compatible with catastrophic extinctions. Science 223, 1177-1179.

Smit, J., van der Kaars, W.A., Rigby, J.K., Jr., 1987. Stratigraphic aspects of the CretaceousTertiary boundary in the Bug Creek area of eastern Montana, U.S.A.: Mémoire de la Société Géologique de France, new series 150, p. 53-73. 
Sprain, C., Renne, P.R., Wilson, G.P., Clemens, W.A., Jr., 2015. High-resolution chronostratigraphy of the terrestrial Cretaceous-Paleogene transition and recovery interval in the Hell Creek region, Montana. Geological Society of America Bulletin 127, 393-409. doi: 10.1130/B31076.1.

Sweet, A.R., Braman, D.R. 1992. The K-T boundary and the contiguous strata in western Canada: Interactions between paleoenvironments and palynological assemblages, Cretaceous Research 13, 31-79.

Sweet, A.R., Braman, D.R. 2001. Cretaceous-Tertiary palynofloral perturbations and extinctions within the Aquilapollenites Phytogeographic Province. Canadian Journal of Earth Sciences 38, 249-269.

Sweet, A.R., Braman, D.R., Lerbekmo, J.F., 1990. Palynofloral response to the K/T boundary events; A transitory interruption within a dynamic system. In: Sharpton, V.L., Ward, P.D. (Eds.), Global catastrophes in Earth history; An interdisciplinary conference on impacts, volcanism, and mass mortality. Geological Society of America Special Paper 247, 457-469.

Sweet, A.R., Braman, D.R., Lerbekmo, J.F., 1999. Sequential palynological changes across the composite Cretaceous-Tertiary boundary claystone and contiguous strata, western Canada and Montana, U.S.A. Canadian Journal of Earth Sciences 36, $743-$ 768.

Swisher, C.C., III, Dingus, L., Butler, R.F., 1993. ${ }^{40} \mathrm{Ar} /{ }^{39} \mathrm{Ar}$ dating and magnetostratigraphic correlation of the terrestrial Cretaceous-Paleogene boundary and the Puercan mammal age. Canadian Journal of Earth Sciences 30, 1981-1996. doi10.1139/e93 174.

Taylor, T.N., Taylor, E.L., Krings, M., 2009. Paleobotany: The Biology and Evolution of Fossil Plants. Academic Press, Burlington. 
Therrien, F., Eberth, D.A., Braman, D.R., Zelenitsky, D.K., 2007. High-resolution organic carbon isotope record across the Cretaceous-Tertiary boundary in south-central Alberta: implications for the post-impact recovery rate of terrestrial ecosystems and use of d13C as a boundary marker. Canadian Journal of Earth Sciences 44, 529-542.

Tobin, T., Ward, P.D., Steg, E.J., Olivero. E.B., Hilburn, I.A., Mitchell, R.N., Diamond, M.R., Raub, T.D., Kirschvink, J.L., 2012. Extinction patterns, d18O trends, and magnetostratigraphy from a southern high-latitude Cretaceous-Paleogene section. Links with Deccan volcanism: Palaeogeography, Palaeoclimatology, Palaeoecology 350,180-188. doi:10.1016/j.palaeo2012.06.029.

Traverse, A., 1988. Plant evolution dances to a different beat. Plant and animal evolutionary mechanisms compared. Historical Biology 1, 227-301.

Tschudy, R.H., 1970. Palynology of the Cretaceous-Tertiary boundary in the northern Rocky Mountain and Mississippi Embayment regions. In: Kosanke, R.M., Cross, A.T., (Eds.), Symposium on palynology of the Late Cretaceous and early Tertiary. Geological Society of America Special Paper 127, 65-111.

Tschudy, R.H., 1984. Palynological evidence for change in continental floras at the Cretaceous Tertiary boundary. In: Berggen, W.A., Van Couvering, J.A. (Eds.), Catastrophes in Earth history: the new uniformitarianism. pp. 315-337.

Tschudy, R.H., Pillmore, C.L., Orth, C.J., Gilmore, J.S., Knight, J.D., 1984. Disruption of the terrestrial plant ecosystem at the Cretaceous-Tertiary boundary, Western Interior. Science 225, 1030-1032.

Vajda, V., Raine, J.I., 2003. Pollen and spores in marine Cretaceous/Tertiary boundary sediments at mid-Waipara River, North Canterbury, New Zealand. New Zealand Journal of Geology and Geophysics 46, 255-273. 
Vajda, V., McLoughlin, S., 2004. Fungal Proliferation at the Cretaceous-Tertiary Boundary. Science 303, 1489.

Vajda, V., McLoughlin, S., 2007. Extinction and recovery patterns of the vegetation across Cretaceous-Palaeogene boundary - a tool for unravelling the causes of the endPermian mass-extinction. Review of Palaeobotany and Palynlogy 144, 99-112.

Vajda, V., Bercovici, A., 2012. Pollen and spore stratigraphy of the Cretaceous-Paleogene mass-extinction interval in the Southern Hemisphere. Journal of Stratigraphy. 36, $154-165$.

Vajda, V., Bercovici, A., 2014. The global vegetation pattern across the CretaceousPaleogene mass extinction interval; a template for other extinction events. Global and Planetary Change, v. 122, pp. 29-49.

Vajda, V., Raine, J.I., Hollis, C.J., 2001. Indication of global deforestation at the CretaceousTertiary boundary by New Zealand fern spike. Science 294, 1700-1702.

Vajda, V., Raine, J.I., Hollis, C.J., Strong, C.P., 2004. Global effects of the Chicxulub impact on terrestrial vegetation - Review of the palynological record from New Zealand Cretaceous/Tertiary boundary. In: Dypvik, H., Clayes, P. (Eds.), Cratering in marine environments and on ice. Springer Verlag. pp. 57-74.

Vajda, V., Lyson, T.R., Bercovici, A., Doman, J., Pearson, D.A., 2013. A snapshot into the terrestrial ecosystem of an exceptionally well-preserved dinosaur (Hadrosauridae) from the Upper Cretaceous of North Dakota, USA. Cretaceous Research 46, 114 122.

Van Valen, L.M., 1978. The beginning of the age of mammals. Evolutionary Theory 4, 4580. 
Van Valen, L.M., Sloan, R.E., 1977. Ecology and extinction of the dinosaurs. Evolutionary Theory 2, 37-64.

Vellekoop, J., Smit, J., van de Schootbrugge, B., Weijers, J.W.H., Galeotti, S., Sinninghe Damsté, J.S., Brinkhuis, H., 2015. Palynological evidence for prolonged cooling along the Tunisian continental shelf following the K-Pg boundary impact. Palaeogeography, Palaeoclimatology, Palaeoecology 426, 216-228.

Wang, S.C., Dodson, P., 2006. Estimating the diversity of Dinosaurs. Proceedings of the National Academy of Sciences 103, 13601-13605. doi10.1073pnas.0606028103.

Ward, P.D., 2006. Impact from the deep. Scientific American 295, 64-71.

Weil, A., Clemens, W.A., 1998. Aliens in Montana: phylogenetically and biogeographically diverse lineages contributed to an earliest Cenozoic community. Geological Society of America Abstracts with Programs 30, 69-70.

Weishampel, D.B., Barrett, P.M., Coria, R.A., Le Loeuff, J., Xu, X., Zhao, X., Sahni, A., Gomani, E.M.P., Noto, C.R., 2004. Dinosaur distribution. In: Weishampel, D.B., Dodson, P.D., Osmólska, H., (Eds.), The Dinosauria (second edition). Berkeley, University of California Press, 517-606.

Whiteside, J.H., Olsen, P.E., Eglington, T., Brookfield, M.E., and Sambrotto, R.N., 2010. Compound-specific carbon isotopes from Earth's largest flood basalt eruptions directly linked to the end-Triassic mass extinction. Proceedings of the National Academy of Sciences of the United States 107, 6721-6725.

Wilf, P., Johnson, K.R., 2004. Land plant extinction at the end of the Cretaceous: a quantitative analysis of the North Dakota megafloral record. Paleobiology 30, 347368. 
Wilf, P., Johnson, K.R., Huber, B.T., 2003. Correlated terrestrial and marine evidence for global climate changes before mass extinction at the Cretaceous-Paleogene boundary. Proceedings of the National Academy of Sciences 100, 599-604.

Wilf, P., Labandeira, C.C., Johnson, K.R., Ellis, B., 2006. Decoupled plant and insect diversity after the end-Cretaceous extinction. Science 313, 1112-1115.

Williams, M.E., 1994. Catastrophic versus noncatastrophic extinction of the dinosaurs: Testing, falsifiability, and the burden of proof. Journal of Paleontology 68, 183-190.

Willumsen, P.S., Vajda, V., 2010. A new early Paleocene dinoflagellate cyst species, Trithyrodinium partridgei: its biostratigraphic significance and palaeoecology. Alcheringa 3, 523-538.

Wilson, G.P., 2004. A quantitative assessment of mammalian change leading up to and across the Cretaceous-Tertiary boundary in northeastern Montana [unpub. Ph.D. dissertation], Berkeley, CA, University of California, 412 p.

Wilson, G.P. 2005. Mammalian faunal dynamics during the last 1.8 million years of the Cretaceous in Garfield County, Montana. Journal of Mammalian Evolution, 53-76.

Wilson, G.P., 2013. Mammals across the K/Pg boundary in northeastern Montana, U.S.A.: Dental morphology and body size patterns reveal extinction selectivity and immigrant-fueled ecospace filling. Paleobiology 39, 429-469.

Wilson, G.P., Evans, A.R., Corfe, I.J., Smits, P.D., Fortelius, M., Jernvall, J., 2012. Adaptive radiation of multituberculates before the extinction of dinosaurs. Nature 483, 457460.

Wilson, G.P., Clemens, W.A. Jr., Horner, J.R., and Harman, J.H., 2014a. Through the End of the Cretaceous in the Type Locality of the Hell Creek Formation in Montana and adjacent areas. Geological Society of America Special Paper 503, 392 p. 
Wilson, G.P., Demar, D.G., Jr., Carter, G., 2014b. Extinction and survival of salamander and salamander-like amphibians across the Cretaceous-Paleogene boundary in northeastern Montana, USA. In; Wilson, G.P., Clemens, W.A. Jr., Horner, J.R., Harman, J.H., (Eds.), Through the End of the Cretaceous in the Type Locality of the Hell Creek Formation in Montana and adjacent areas. Geological Society of America Special Paper 503, 271-297. doi:10/1130/2014.2503(10).

Wolbach, W. S., Lewis, R.S., Anders, E., 1985. Cretaceous Extinctions: Evidence for Wildfires and Search for Meteoritic Material. Science, 240, 167-170.

Wolbach, W. S., Gilmour, I., Anders, E., Orth, C.J., Brooks, R.R., 1988. Global fire at the Cretaceous-Tertiary boundary. Nature 334, 665-669.

Wolfe, J.A., 1987. Late Cretaceous-Cenozoic history of deciduousness and the terminal Cretaceous event. Paleobiology 13, 215-226.

Wolfe, J.A., 1991. Palaeobotanical evidence for a June 'impact winter' at the CretaceousTertiary boundary. Nature 352, 420-423.

Wolfe, J.A., Upchurch, G.R., Jr., 1986. Vegetation, climatic and floral changes at the Cretaceous-Tertiary boundary. Nature 324, 148-152.

Wolfe, J.A., Upchurch, G.R., Jr., 1987. Leaf assemblages across the Cretaceous-Tertiary boundary in the Raton Basin, New Mexico and Colorado. Proceedings of the National Academy of Science 84, 5096-5100. 


\section{List of Figures}

Figure 1. Geological map of Maastrichtian exposures, northern Great Plains, USA. Redrawn from Johnson et al., 2002.

Figure 2. Stratigraphy of Maastrichtian formations, northern Great Plains, USA. Redrawn from Johnson et al., 2002.

Figure 3. Fluvial faces in the Hell Creek and Fort Union Formations. Full sedimentological descriptions of these facies and their relationships in the Hell Creek fluvial system are found in Fastovsky, (1987) and Fastovsky and McSweeney (1987). A: cross-stratified sandstone, representing channel deposits; B: Inclined heterolithic strata representing point bar deposits C: banded purple and green mudstones, representing gleyed floodplain paleosol horizons (mudstone bisected by light colored, sandstone deposit); D: mudstone with roots, paleosols; E: An in-situ dinosaur bone eroding out of the Hell Creek Formation; F: laminated siltstones ("variegated" beds), representing earliest Paleogene flooding; G: The formation contact lignite; H: Several lignite beds within the Fort Union Formation, representing local peat mire deposition.

Figure 4. A: Extensive outcrop of the upper part of the Hell Creek Formation near Pretty Butte, showing typical grey/green/purple gleyed paleosols, and Hell Creek - Fort Union contact at the very top. B: Hell Creek - Fort Union contact, as seen at Mountain Goat Lake Butte, southwestern North Dakota. The contact is easily recognized by a set of features such as color change (especially from homogeneous darker gray to golden yellow and lighter banded units), break in slope, and the presence of modern vegetation just above the contact. 
Figure 5. A: The K-Pg boundary at the Pyramid Butte section. The locality was first described by Johnson et al. (1989) and is the first K-Pg locality identified in southwestern North Dakota associated to iridium anomaly and palynological extinction. Black arrow points to section enlarged on the right. B: Closeup view of the Hell Creek - Fort Union formation contact of the Pyramid Butte section, at the base of the formation contact lignite. The $\mathrm{K}-\mathrm{Pg}$ boundary was identified at the top of the lignite, by iridium anomaly, shocked quartz, and palynological extinction Johnson et al. (1989). Note that the Pyramid Butte section does not preserve the K-Pg boundary clay or spherules. C: The K-Pg boundary at the Mud Buttes section. Mud Buttes was first described by Nichols and Johnson (2002), and is the second KPg boundary section in southwestern North Dakota that shows direct evidences of the Chicxulub impact. Black arrow points to section enlarged on the right. D: The K-Pg boundary layer at Mud Buttes. The sequence shows a 1-cm-thick pinkish clay layer (low angle ejecta), overlain by a $\sim 2$-cm-thick orange layer containing altered spherules (high angle ejecta). The top part features shocked quartz and the maximum concentration of iridium. Horizontal worm burrows were identified by Chin et al. (2013) as some of the earliest traces of animal life recovering from the $\mathrm{K}-\mathrm{Pg}$ mass extinction.

Figure 6. The various modes of plant preservation within the Hell Creek Formation. A: Diverse leaf compressions of angiosperm leaves (and one conifer) from the uppermost part of the Hell Creek Formation. B: Numerous leaf compressions of angiosperm leaves from the lowermost part of the Fort Union Formation, showing a very low diversity (FUI assemblage). C: Outcrop in the upper part of the Hell Creek Formation with a layer of ironstone (lower part) that preserve 3D casts of seeds and cones. D: Permineralized Metasequoia dakotensis cones (left) and Cercidiphyllum seeds (right), preserved as ironstone 3D casts. E: Silicified permineralized wood from the Hell Creek Formation. F: A piece of charcoal (fusain) from the 
formation contact lignite ( $\sim 3 \mathrm{~cm}$ long). G: Micrograph of a Hell Creek palynofacies, showing wood fragments, amorphous organic matter, and a specimen of Wodehouseia spinata. H: A specimen of Bisonia niemi (HCIII) from the upper part of the Hell Creek Formation, showing hole feeding type of insect damage (black arrow).

Figure 7. Compilation of vertebrate, macroflora and insect damage diversity trends over the last 1.3 Myr of the Cretaceous in the Marmarth area, North Dakota, USA. Mean annual paleotemperatures are derived from leaf margin analysis. The Sunset Butte section is used as a baseline for the thickness of the Hell Creek Formation in North Dakota, paleontological data is compiled from a multitude of localities from within the Marmarth area. 


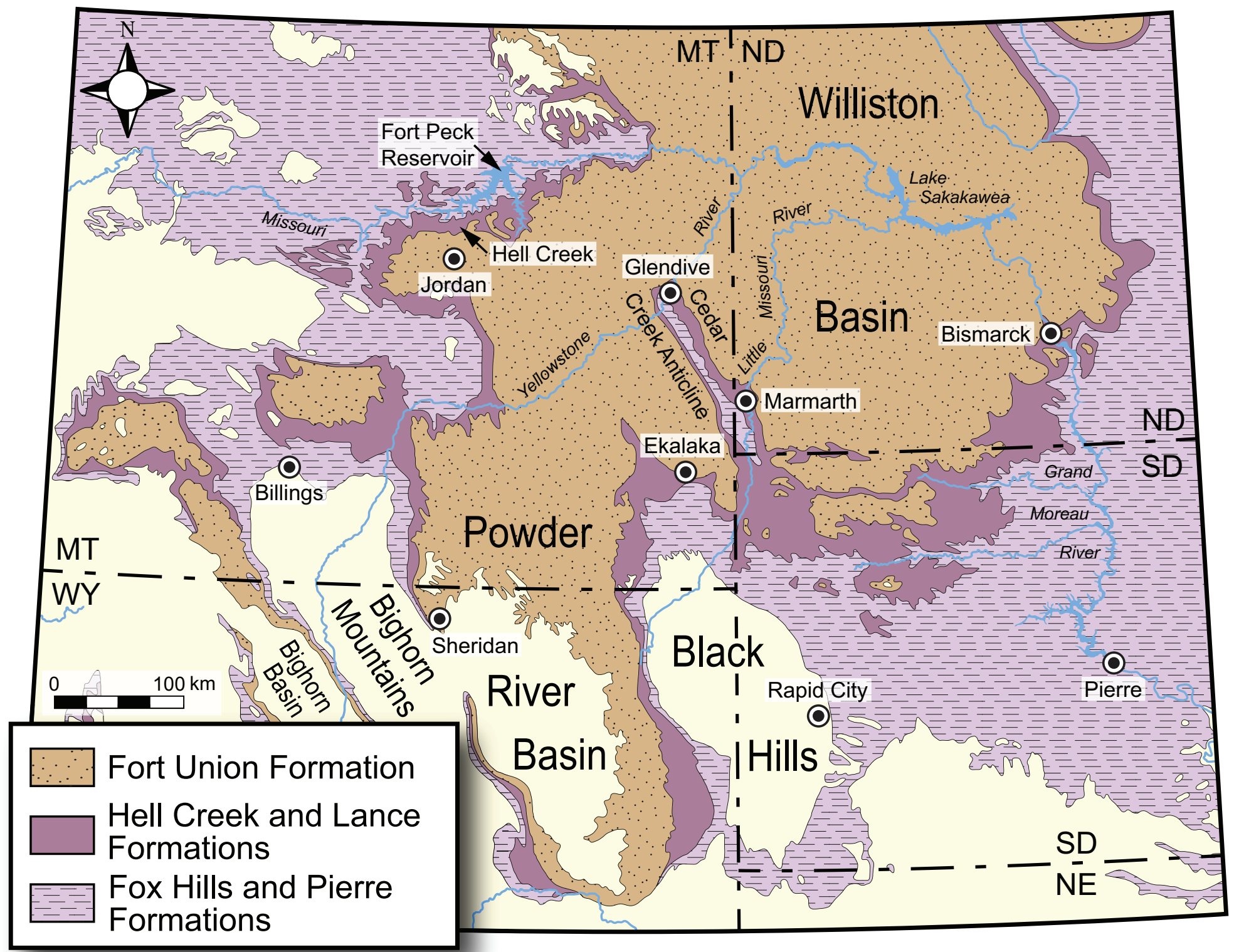



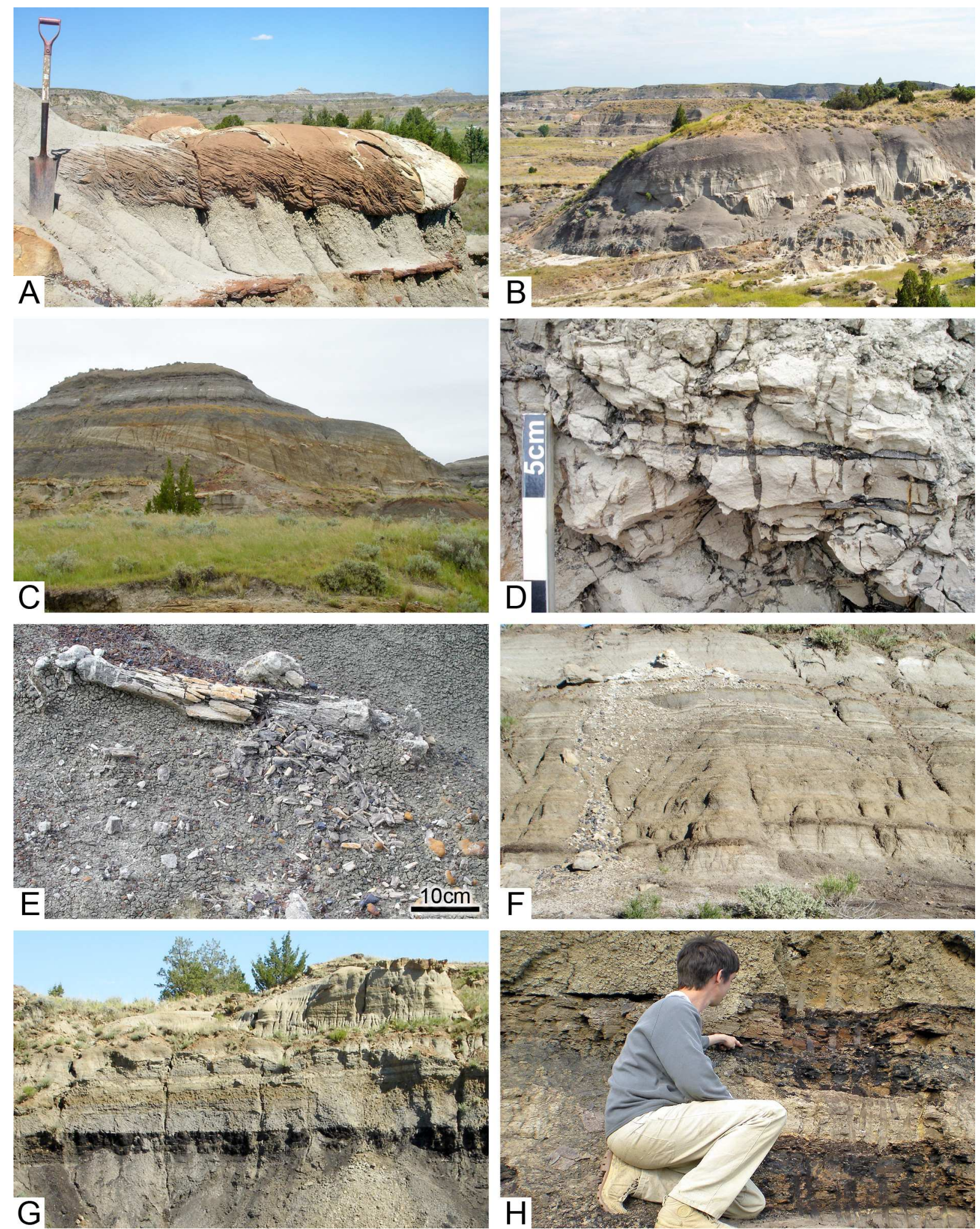

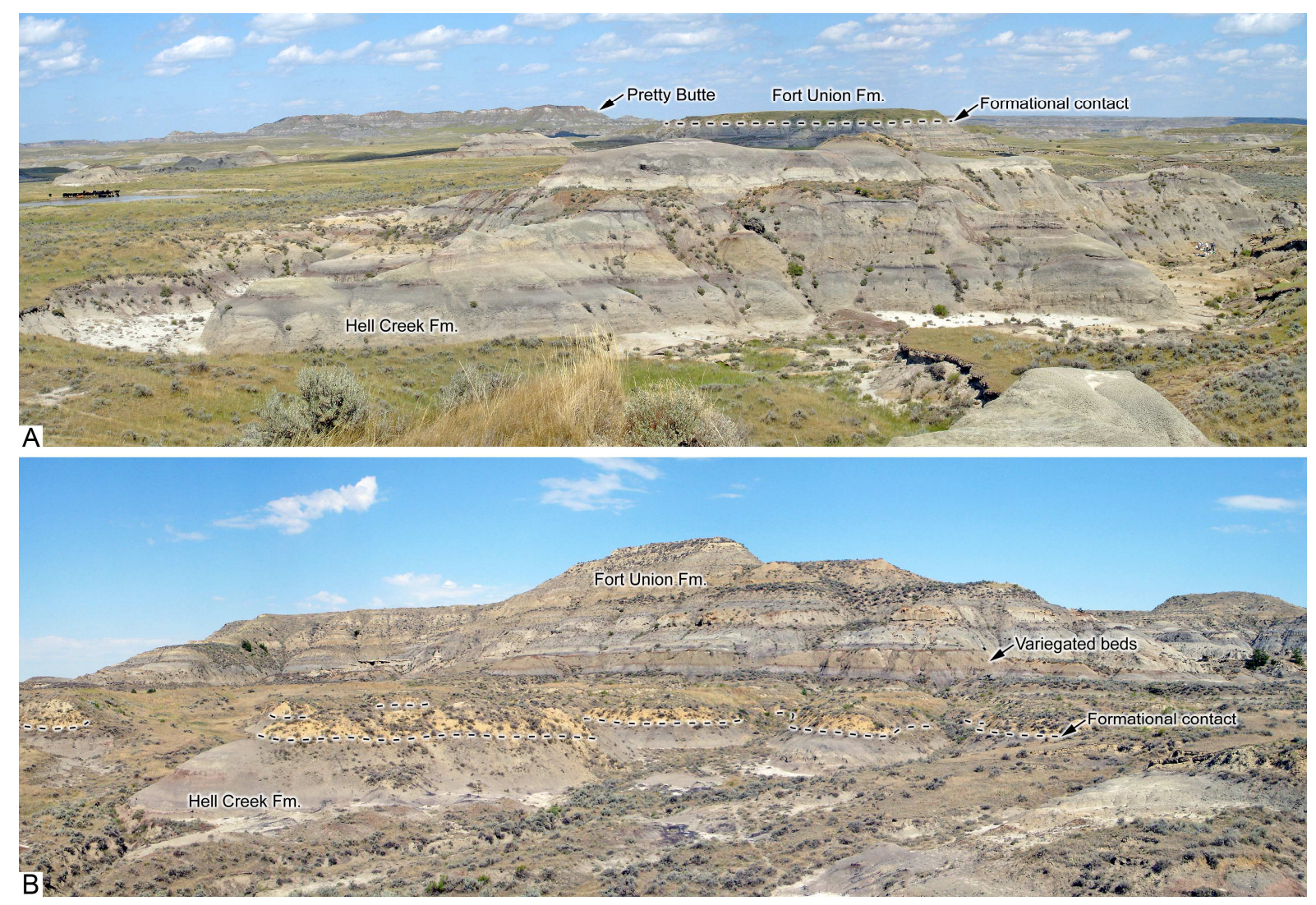

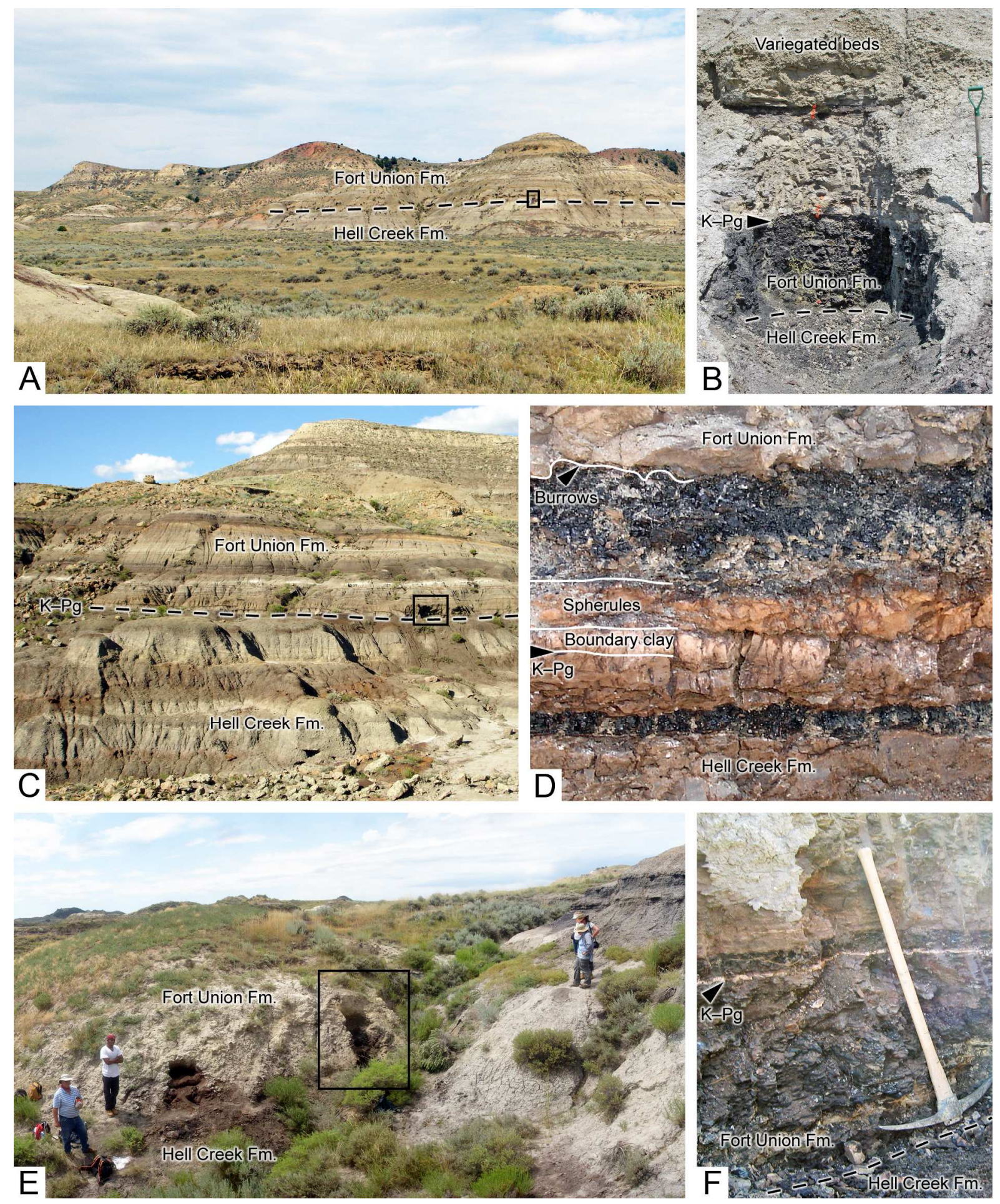

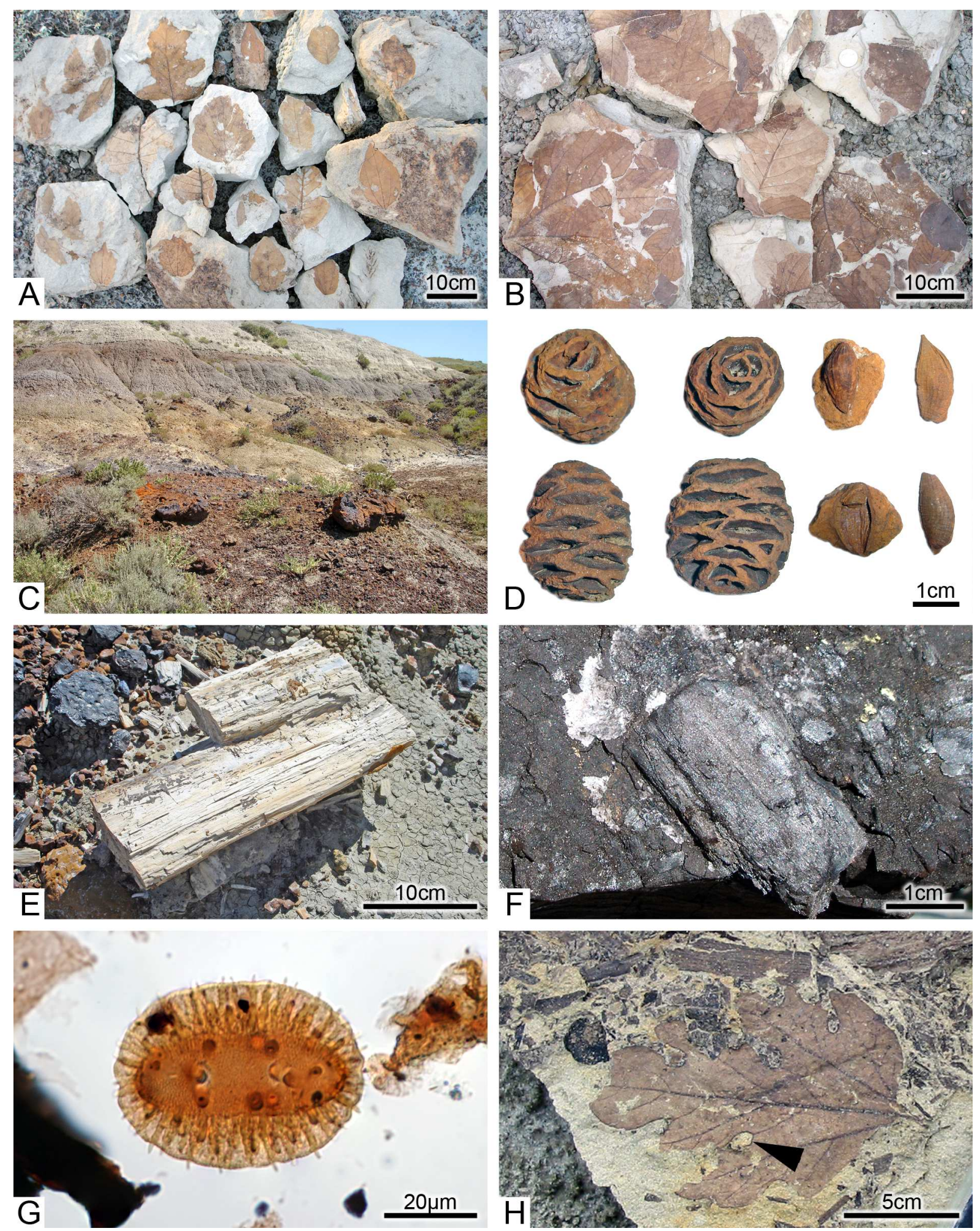


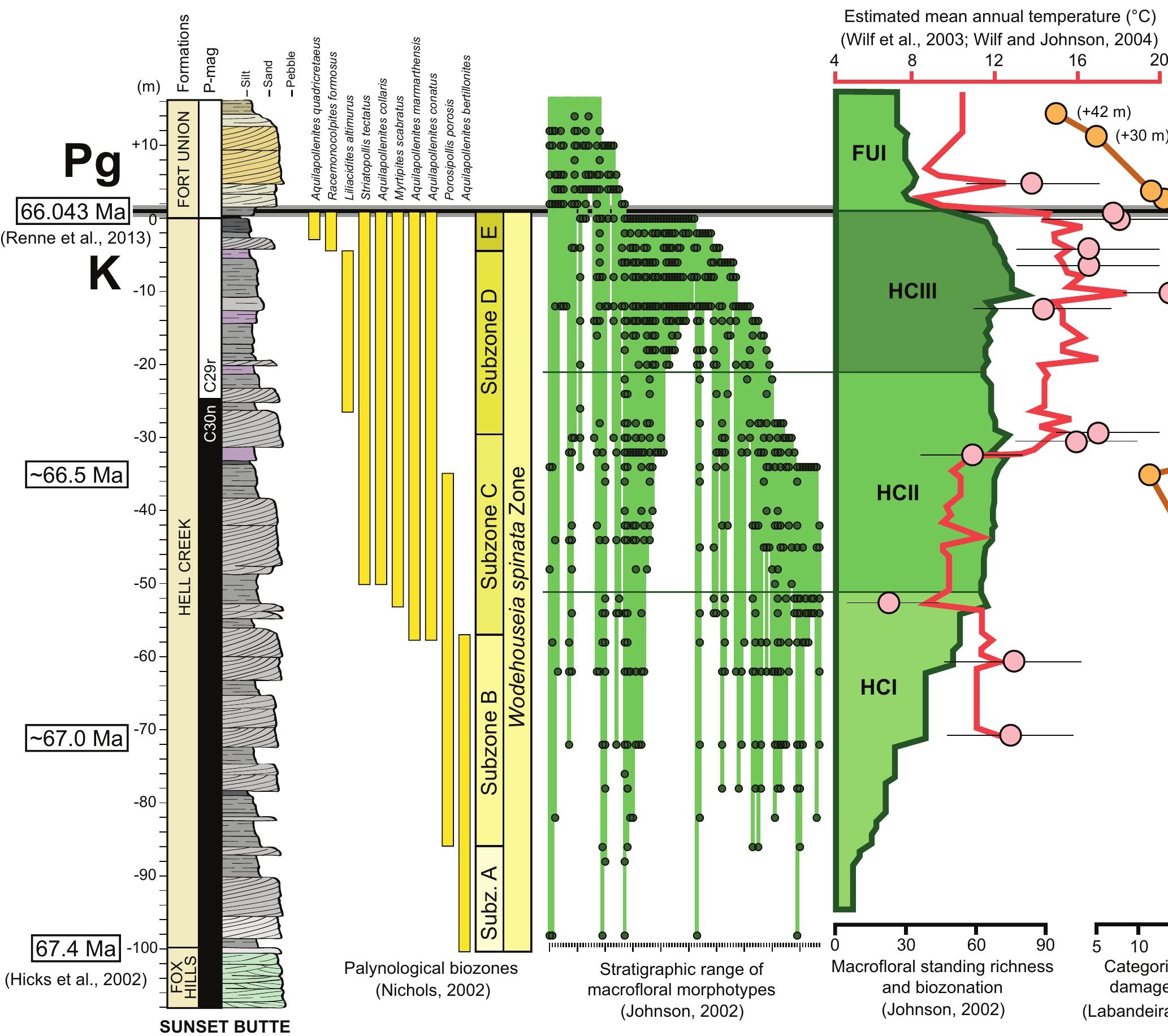

